\title{
Review Article \\ Properties and Microstructures of Sn-Ag-Cu-X Lead-Free Solder Joints in Electronic Packaging
}

\author{
Lei Sun and Liang Zhang \\ School of Mechanical and Electrical Engineering, Jiangsu Normal University, Xuzhou 221116, China \\ Correspondence should be addressed to Liang Zhang; zhangliang@jsnu.edu.cn
}

Received 6 October 2014; Accepted 23 November 2014

Academic Editor: Hossein Moayedi

Copyright ( 2015 L. Sun and L. Zhang. This is an open access article distributed under the Creative Commons Attribution License, which permits unrestricted use, distribution, and reproduction in any medium, provided the original work is properly cited.

\begin{abstract}
SnAgCu solder alloys were considered as one of the most popular lead-free solders because of its good reliability and mechanical properties. However, there are also many problems that need to be solved for the SnAgCu solders, such as high melting point and poor wettability. In order to overcome these shortcomings, and further enhance the properties of SnAgCu solders, many researchers choose to add a series of alloying elements ( $\mathrm{In}, \mathrm{Ti}, \mathrm{Fe}, \mathrm{Zn}, \mathrm{Bi}, \mathrm{Ni}, \mathrm{Sb}, \mathrm{Ga}, \mathrm{Al}$, and rare earth) and nanoparticles to the $\mathrm{SnAgCu}$ solders. In this paper, the work of $\mathrm{SnAgCu}$ lead-free solders containing alloying elements and nanoparticles was reviewed, and the effects of alloying elements and nanoparticles on the melting temperature, wettability, mechanical properties, hardness properties, microstructures, intermetallic compounds, and whiskers were discussed.
\end{abstract}

\section{Introduction}

Tin-lead $(\mathrm{SnPb})$ solders have been widely used in electronic packaging. However, due to the increasing environmental and human health concerns over the toxicity of lead, governments of many countries have established laws to prohibit the use of $\mathrm{Pb}$ from electronic application. Therefore, investigation of lead-free solder has become an important research topic in the field of electronic packaging.

In recent years, to replace the conventional $\mathrm{Sn}-\mathrm{Pb}$ solder alloys, several types of Sn-based lead-free solders such as $\mathrm{SnAg}, \mathrm{SnCu}, \mathrm{SnZn}, \mathrm{SnBi}, \mathrm{SnIn}$, and $\mathrm{SnAgCu}$ have been developed. Among series of lead-free solders, $\mathrm{SnAgCu}$ has been proposed as the most promising lead-free solder for replacement of traditional tin-lead solder owing to its good reliability, excellent creep resistance, and thermal fatigue characteristics [1-3]. However, there are still many unresolved issues. For example, $\mathrm{SnAgCu}$ solder has a high melting point, poor wettability, coarser microstructures, and so forth. In order to further enhance the properties of lead-free solder, two methods are taken. The first method is to add alloying elements to the $\mathrm{SnAgCu}$ solder, such as $\mathrm{Ga}$ element which can improve the wettability. And the addition of rare earth elements can enhance the comprehensive performance.
Another method is to add micro- or nanoparticles. It mainly comprises of metal particles, compound particles, ceramic particles, the carbon nanotubes, and the polymer particles. With the changes of added particles in its type and size, the properties of $\mathrm{SnAgCu}$ solder are different. Not only can adding metal particles change the microstructure of the solder, but also there will be a new phase in the solder matrix, while adding compound particles or ceramic particles cannot form a new phase.

In this review, we summarize the development of $\mathrm{SnAgCu}$ solder alloys and analyze the effects of adding the fourth elements on the melting temperature, wettability, mechanical properties, hardness properties, microstructures, and intermetallic compounds (IMC). At the same time, we will also discuss the Sn whisker, and some suggestions have been put forward which maybe solve this issue.

\section{Melting Temperature}

Melting temperature is an important factor for the development of new lead-free solders. A promising solder alloy should have a low melting temperature and a narrow melting range [4]. As we all know, the eutectic $\mathrm{SnPb}$ has a melting point of $183^{\circ} \mathrm{C}$, while the $\mathrm{SnAgCu}$ solder melting point is 
$217^{\circ} \mathrm{C}, 34^{\circ} \mathrm{C}$ higher than that of the eutectic SnPb. Such high melting temperature will increase the reflowing temperature and lead to thermal damage of the polymer substrate [5]. Meanwhile, it also enhances the dissolution rate and solubility of $\mathrm{Cu}$ in the molten solder, thus improving the rate of formation of IMCs. This is the reason that the IMCs layer of $\mathrm{SnAgCu}$ thicker than $\mathrm{Sn}-\mathrm{Pb}$. Hence, some researchers expect to add the fourth elements to decrease the melting temperature of $\mathrm{SnAgCu}$ solders.

Trace amount of indium (In) added to the SnAgCu leadfree solder can change the melting behavior obviously. It was shown in the literature [6] that adding $3.0 \mathrm{wt} . \%$ of In the solidus and liquidus temperatures decreased 21.7 and $11.5^{\circ} \mathrm{C}$, respectively, as compared with 219.4 and $241.7^{\circ} \mathrm{C}$ for the $\mathrm{Sn} 0.3 \mathrm{Ag} 0.7 \mathrm{Cu}$ solder. But the In is very expensive, the addition of In can increase the cost of lead-free solders. Chuang et al. [7] proposed that the effect of $\mathrm{Ti}$ on the melting point of Sn3.5Ag0.5Cu (SAC) solder alloy. With the addition of $\mathrm{Ti}$ element, the melting temperatures change slightly. The liquidus temperatures are 220.95, 220.86, and $219.47^{\circ} \mathrm{C}$ for the SAC- $x \mathrm{Ti}$ solder alloys with $\mathrm{Ti}$ contents of $0.25,0.5$, and $1.0 \mathrm{wt} . \%$, respectively. Moreover, the melting range is decreased from 4.66 to $2.88^{\circ} \mathrm{C}$. Generally speaking, the narrow melting range of the solder means excellent thermal properties. It is mainly attributed to the narrow melting range explaining that solders exist as part liquid for a very short time during solidification and can form reliable joints during the reflow process. Figure 1 represents the differential scanning calorimetry (DSC) curve of $\mathrm{SnAgCu}$ bearing different manganese $(\mathrm{Mn})$ and titanium $(\mathrm{Ti})$. It is

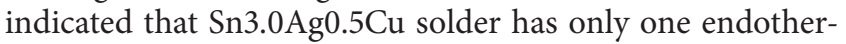
mic peak, yet it has two peaks for the Sn1.0Ag0.5Cu (SAC) solder. Meanwhile, worthy of notice is that the degree of undercooling for proeutectic Sn was significantly affected by the addition of trace alloying elements ( $\mathrm{Mn}$ and $\mathrm{Ti}$ ) into SAC solder alloy. The SAC-0.5Ti sample showed an extremely suppressed undercooling of only $4^{\circ} \mathrm{C}$ [8]. The addition of Fe into $\mathrm{SnAgCu}$ solder did not change much of the melting temperature [9]. The DSC results demonstrated a single peak of $\mathrm{Sn3} .6 \mathrm{Ag} 0.9 \mathrm{Cu}$ solder. However, there are two obvious endothermic peaks $\left(220^{\circ} \mathrm{C}\right.$ and $\left.235^{\circ} \mathrm{C}\right)$ that appear for the $\mathrm{SnAgCu}-0.2 \mathrm{Fe}$ solder alloy. This shows that melting occurred over a range of temperatures. It may be ascribed to the peaks overlapped; the first peak may indicate that the solder was partially fused. The addition of Fe most likely resulted in shifting of the melting point from the eutectic point to near the eutectic point, and the melting point of the solder is in the range of 222.87 to $230^{\circ} \mathrm{C}$, which is higher than the $\mathrm{SnAgCu}$ solder melting point $\left(217^{\circ} \mathrm{C}\right)$. When adding $0.6 \mathrm{wt} . \%$ $\mathrm{Fe}$, only a single endothermic peak at $221.35^{\circ} \mathrm{C}$ was found, showing that it has a eutectic composition. El-Daly et al. [10] studied the DSC profiles of Sn1.0Ag0.3Cu solder. The DSC revealed two endothermic peaks between $220.1^{\circ} \mathrm{C}$ and $227.2^{\circ} \mathrm{C}$. The two peaks indicated two steps in the melting process of $\mathrm{SnAgCu}$ solder. Based on the ternary $\mathrm{SnAgCu}$ phase diagram [11], the two steps were owed to the melting of ternary eutectic $\beta-\mathrm{Sn}+\mathrm{Ag}_{3} \mathrm{Sn}+\eta \mathrm{Cu}_{6} \mathrm{Sn}_{5}$ phase and primary $\beta$-Sn. However, for $\mathrm{SnAgCu}$ solder containing $\mathrm{Zn}$, only one endothermic peak appears in the DSC curve, and the melting

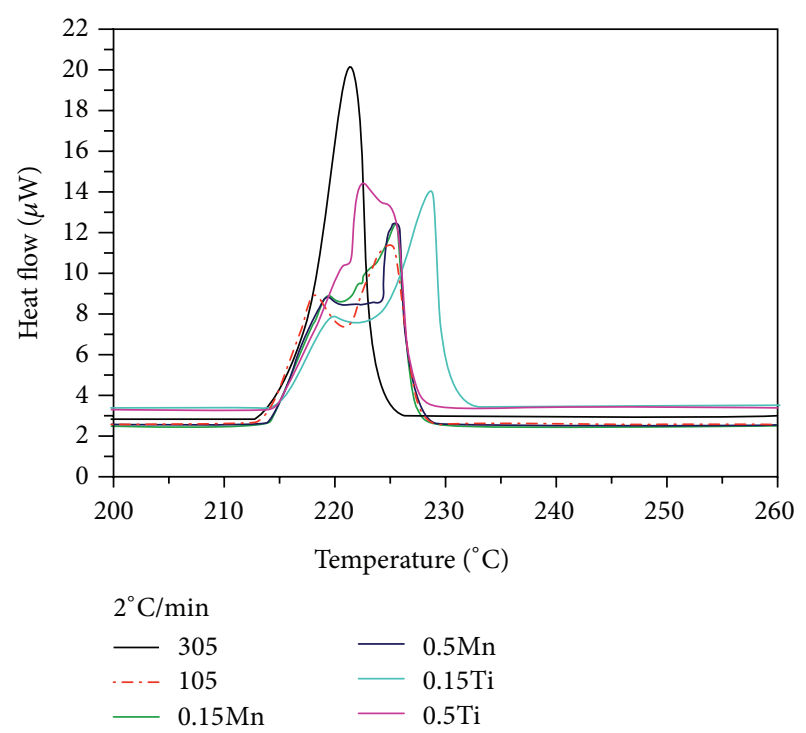

(a)

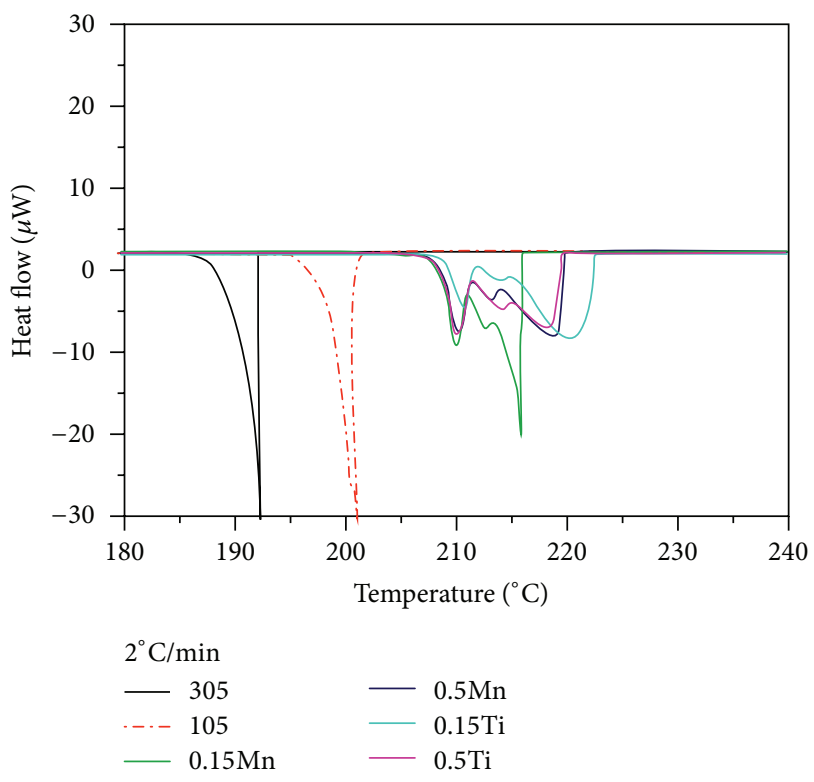

(b)

FIGURE 1: DSC curves of the samples: (a) upon heating and (b) upon cooling [8].

temperatures were 222.8 and $220.8^{\circ} \mathrm{C}$ for the SAC-2.0Zn and SAC-3.0Zn, respectively. The addition of Bi decreases the melting point of $\mathrm{Sn3} .8 \mathrm{Ag} 0.7 \mathrm{Cu}$ (SAC) solder [12]. It is found that the solidus temperatures of SAC-2.0Bi and SAC4.0Bi were 213.08 and $206.40^{\circ} \mathrm{C}$, respectively. However, when adding too much $\mathrm{Bi}$, solder joint peeling will appear. DSC scan of low-Ag Sn0.5Ag0.7Cu (SAC) solder bearing Ni and the results showed that the addition of $\mathrm{Ni}$ had little effect on the melting temperature [13]. The peak temperatures of SAC, SAC-0.05Ni, and SAC-0.1Ni solders were 221.1, 222.9, and $223.4^{\circ} \mathrm{C}$. Moreover, the values of melting range were 12.6, 11.9 , and $12.8^{\circ} \mathrm{C}$ for the SAC, SAC- $0.05 \mathrm{Ni}$, and SAC- $0.1 \mathrm{Ni}$, respectively. It is very close to $11.5^{\circ} \mathrm{C}$ for the $\mathrm{SnPb}$ solder [14]. It was also reported in the literature [15]. 
It is well known that the addition of a small amount of RE elements in the metals can greatly enhance their properties [16]. However, it does not significantly alter the melting point. The DSC curves of Sn3.9Ag0.7Cu and Sn3.9Ag0.7Cu0.5RE solders were studied by Dudek and Chawla [17]; all solders show a single endothermic peak between $217^{\circ} \mathrm{C}$ and $219^{\circ} \mathrm{C}$, showing the onset of melting for the $\mathrm{SnAgCu}$ solder. It is revealed that the addition of $\mathrm{RE}$ elements into $\mathrm{Sn3} .9 \mathrm{Ag} 0.7 \mathrm{Cu}$ solder did not affect the melting characteristics. Moreover, it is also found that the addition of La exhibits minimal impact, while the addition of $\mathrm{Ce}$ and $\mathrm{Y}$ increases the onset temperature by approximately $2^{\circ} \mathrm{C}$.

Recently, many researchers are also investigating the addition of nanoparticles into $\mathrm{SnAgCu}$ solders for providing better properties and microstructures. Xiang et al. [18] reported that the addition of $\mathrm{Mn}$ nanoparticles did not change significantly the melting temperature of Sn3.8Ag0.7Cu (SAC) solder alloy. The results showed that the onset melting temperatures of SAC- $0.12 \mathrm{Mn}, \mathrm{SAC}-0.18 \mathrm{Mn}$, and SAC-0.47Mn composite solders were $217^{\circ} \mathrm{C}, 217.3^{\circ} \mathrm{C}$ and $217.5^{\circ} \mathrm{C}$, respectively. Small amounts of $\mathrm{SiC}$ nanoparticles added to the Sn3.8Ag0.7Cu solder do not change much of the melting temperature. The well-defined endothermic peak shifts from $219.9^{\circ} \mathrm{C}$ to $218.9^{\circ} \mathrm{C}$ with the addition of 0.2 wt.\% $\mathrm{SiC}$ [19]. $\mathrm{Al}_{2} \mathrm{O}_{3}$ nanoparticles have been added to the $\mathrm{Sn} 3.5 \mathrm{Ag} 0.5 \mathrm{Cu}$ solder alloy. During the heating process of the DSC analysis, the $\mathrm{Sn} 3.5 \mathrm{Ag} 0.5 \mathrm{Cu}$ solder exhibited a eutectic alloy with a melting point of $221.2^{\circ} \mathrm{C}$, which has been increased slightly with the increase of the amount of nano- $\mathrm{Al}_{2} \mathrm{O}_{3}$ particles [20]. To identify the effects of different joint fabrication methods and the amount of $\mathrm{TiO}_{2}$ addition on the Sn3.0Ag0.5Cu (SAC) solder, DSC analysis was used. DSC analysis was used. The results showed that the melting point of SAC solder and the solder bearing $1 \mathrm{wt}$. $\% \mathrm{TiO}_{2}$ nanoparticles ranged from $217^{\circ} \mathrm{C}$ to $217.64^{\circ} \mathrm{C}$, with only a eutectic peak [21]. A similar phenomenon in other studies on the SAC composite solders was observed [22]. DSC analysis was carried out to understand the influence of $\mathrm{ZnO}$ nanoparticles addition to the $\mathrm{Sn} 3.5 \mathrm{Ag} 0.5 \mathrm{Cu}$ (SAC) solder on its melting temperature. From DSC results, it is indicated that the melting temperatures of plain SAC solder and SAC$0.5 \mathrm{ZnO}$ composite solder were about $221.18^{\circ} \mathrm{C}$ and $222.16^{\circ} \mathrm{C}$, respectively, with only a eutectic peak [23]. The melting behavior of Sn3.0Ag0.5Cu solder reinforced with nanosized $\mathrm{ZrO}_{2}$ particles were studied by Gain and Chan [24]. The melting temperature was increased by less than $1^{\circ} \mathrm{C}$ when the amount of $\mathrm{ZrO}_{2}$ nanoparticles was $1 \mathrm{wt} . \%$.

In summary, adding alloying elements and nanoparticle on the melting temperature has little effect. However, the new lead-free wave soldering and reflow oven that can make soldering below $250^{\circ} \mathrm{C}$ have been developed. Therefore, the above elements added to the $\mathrm{SnAgCu}$ solder can meet the requirement of the present soldering process and there is no need to make adjustment in the current reflow process. Besides, in future research, we may only need to ensure that the addition of elements can slightly influence the melting of SnAgCu solders.

\section{Wettability}

Wettability of solder can be defined as the ability of the molten solder to spread over on a substrate during the reflow process [25]. For the reflow process, the heating temperature at a certain condition, only a good wettability to the surface of the base material to form good wet spreading joints, namely which is to form solder joints. And the solder joints bear the entire electronic device the role of mechanical support and electrical connections; thus the solder joints directly determine the performance of electronic products. For traditional $\mathrm{SnPb}$ solder, due to the existence of $\mathrm{Pb}$, the solder alloy owns better wettability. But for lead-free solders, the wettability may be dropped obviously due to the replacement of $\mathrm{Pb}$. In order to improve the wettability of solder, the addition of alloying element is a hot research investigator. Generally, there are many methods to measure the wettability, but the wetting balance method and spreading method are considered the relatively versatile methods.

The addition of a small amount of In into $\mathrm{SnAgCu}$ solder was investigated by Moser et al. [26]. The wetting angle was decreased from $37^{\circ}$ to $22^{\circ}$ with the addition of 75 at. $\%$ of In. The wetting balance tests were conducted in air to show the wettability of Sn3.6Ag0.9Cu- $x$ Fe by Fallahi et al. [9]. It is found that the addition of $0.2 \mathrm{wt} . \% \mathrm{Fe}$ increased the wetting force and reduced the wetting angle. However, the Fe was added to more than 0.6 wt.\%, which resulted in a lower wettability. Zn element was incorporated into Sn3.8Ag0.7Cu solders by Zhang et al. [27]. The wettability of $\mathrm{SnAgCu}$ solders can be improved with the addition of $\mathrm{Zn}$. When the content of $\mathrm{Zn}$ was up to $0.8 \%$, Sn3.8Ag0.7Cu solder got the smallest angle. However, with the addition of $3 \% \mathrm{Zn}$, wetting angle was the largest. This can be attributed to the $\mathrm{Zn}$ is easily oxidized; the formation of oxide residue during soldering may worsen the wettability of $\mathrm{SnAgCu}$ solder. The addition of trace amount of $\mathrm{Bi}$ into $\mathrm{SnAgCu}$ solders can change the wetting behavior. Rizvi et al. [28] demonstrated by experiment that the effect of $1.0 \mathrm{wt} . \% \mathrm{Bi}$ on the wetting behavior of $\mathrm{Sn} 2.8 \mathrm{Ag} 0.5 \mathrm{Cu}$ solder compared with $\mathrm{Sn}-37 \mathrm{~Pb}$ alloy. It is indicated that the wetting behavior of $\mathrm{Sn} 2.8 \mathrm{Ag} 0.5 \mathrm{Cu} 1.0 \mathrm{Bi}$ solder is less than that of the tradition $\mathrm{SnPb}$ solder for all flux types and solder bath temperatures. However, due to a high soldering temperature promote the diffusion process, thus reducing the wetting angle and improving of the wetting behavior. Moreover, the wetting behavior of $\mathrm{Sn} 2.8 \mathrm{Ag} 0.5 \mathrm{Cu} 1.0 \mathrm{Bi}$ solder on $\mathrm{Ni}$ substrate was lower than that on $\mathrm{Cu}$ substrate. Researchers attribute to $\mathrm{Ni}$ atoms diffused into the solder through the intermetallic compounds (IMCs) much slower than did the $\mathrm{Cu}$ atoms. Moser et al. [29] have also investigated the effect of $\mathrm{Bi}$ on the $\mathrm{SnAgCu}$ solder under Ar- $\mathrm{H}_{2}$ protective atmosphere and found that the $\mathrm{Ar}-\mathrm{H}_{2}$ atmosphere can better decrease the surface tension and improve the wettability. It is due to inert gas may protect the solder decreases the chance of liquid solder in contact with oxygen. Sn0.5Ag0.7Cu solder bearing Ga element was researched by Luo et al. [30]. The results show that the wetting time and wetting forces vary as a function of $\mathrm{Ga}$ when the $\mathrm{Ga}$ was added to the $\mathrm{Sn} 0.5 \mathrm{Ag} 0.7 \mathrm{Cu}$ solder up to $0.5 \%$, resulting in a decrease in the values of mean wetting 


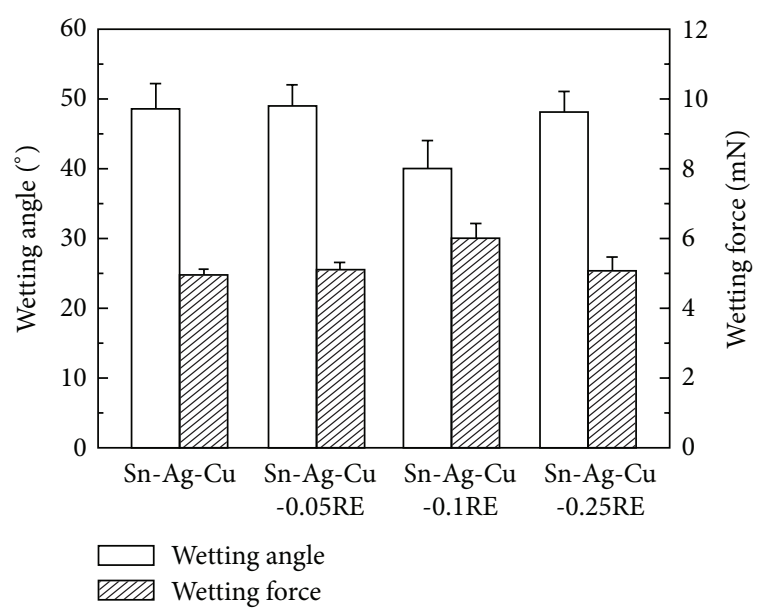

Figure 2: Wetting angle and force of Sn3.5Ag0.7Cu- $x$ RE [35].

time (the wetting force exhibits the increase trend). With a further increase of $\mathrm{Ga}$ addition, increase of the wetting time can be found. Because of the surface-active feature of $\mathrm{Ga}, \mathrm{Ga}$ would accumulate at solder interface in the melting state; then the surface tension of the liquid solder was decreased [31]. Hence, the new composite solders showed better wettability. $\mathrm{Lu}$ et al. [32] confirmed that the addition of $\mathrm{Mg}$ element into SnAgCu solder alloy worsens the wetting behavior because $\mathrm{Mg}$ is very prone to oxidation, and the formation of oxide film increases the surface tension of the liquid solder thus hindering the solder from spreading over the $\mathrm{Cu}$ substrate.

Rare earth (RE) elements have been called the "vitamin" of metals, which means that a small amount of RE elements can obviously enhance the properties of metals [33]. In a series of performance of lead-free solder, the wettability of adding rare earth elements is the most obvious improvement. Yu et al. [34] has investigated the effect of $\mathrm{RE}$ elements ( $\mathrm{Ce}$ and $\mathrm{La}$ ) on the $\mathrm{SnAgCu}$ solder, where the soldering temperature was $250^{\circ} \mathrm{C}$ and RMA flux was used. It is found that the wetting angle of $\mathrm{Sn} 2.5 \mathrm{Ag} 0.7 \mathrm{Cu}$ is higher than $\mathrm{Sn} 3.5 \mathrm{Ag} 0.5 \mathrm{Cu}$ because of the higher melting point of $\mathrm{Sn} 2.5 \mathrm{Ag} 0.7 \mathrm{Cu}$. And when RE is less than $0.1 \mathrm{wt} . \%$, the wetting angle of Sn3.5Ag0.7Cu decreased with RE increases. Whereas the content is higher than $0.1 \mathrm{wt} . \%$, the wetting angle will increase. Similar result was found by Law et al. [35]. Figure 2 shows that the wetting angle was decreased with the addition of RE elements. However, an excessive amount of RE element addition, the wetting angle will increase. The heavy rare earth element $\mathrm{Y}$ can improve the wettability of Sn3.8Ag0.7Cu solder, and the spreading areas increased and the contact angles decreased as the content of Y increased. When adding $0.15 \mathrm{wt} . \% \mathrm{Y}$, the spreading areas and the wetting angles reached the peak, but when Y exceeded $0.15 \mathrm{wt} . \%$, the wettability of the composite solder decreased obviously [36]. Trace rare earth element Er was incorporated into Sn3.8Ag0.7Cu solder which can change the wetting behavior [37]. When the content of Er is less than $0.25 \mathrm{wt} . \%$, the spreading areas will increase with the addition of Er element. However, as the content of Er element continues to increase

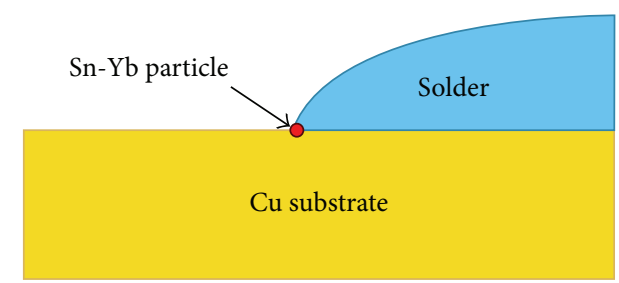

FIGURE 3: Schematic of Yb effect on wetting angle [40].

up to $1.0 \mathrm{wt} . \%$, the spreading areas will decrease. The wetting behavior of $\mathrm{SnAgCu}$ solder is improved with the addition of Pr element. Gao et al. [38, 39] found that trace amount of $\mathrm{Pr}$ and $\mathrm{Nd}$ addition could remarkably improve the wetting behavior of $\mathrm{Sn} 3.8 \mathrm{Ag} 0.7 \mathrm{Cu}$ solder, where the optimal wetting behavior was achieved as the RE content is about 0.05 wt.\% because of the lower surface tension caused by RE elements. The addition of $\mathrm{Yb}$ into $\mathrm{SnAgCu}$ was investigated by Zhang et al. [40]. As a result, the contact angles decreased as the content of $\mathrm{Yb}$ increased. When the addition of $\mathrm{Yb}$ was $0.05 \%$, the contact angle can decrease to the peak value, but as the $\mathrm{Yb}$ content exceeded $0.05 \%$, the contact angles increased obviously. Due to the higher affinity $\mathrm{Sn}$ of rare earths in the solder alloys. Firstly, the Sn tend to react with $\mathrm{Yb}$ to form Sn$\mathrm{Yb}$ particles, and the reaction is easy to go on when the Sn$\mathrm{Yb}$ particles adhere to the substrate to nucleate, particularly for the nucleation of particles at the triple point in Figure 3; when the particles exist at the triple point, the balance among the gas, solid, and liquid will be broken. Effects of addition of rare earth element $\mathrm{Ce}$, atmosphere, and temperature on the wetting behavior of $\mathrm{SnAgCu} x \mathrm{Ce}$ solders were studied by Wang et al. [41]. The results indicate that with the addition of $\mathrm{Ce}$, the wetting behavior of $\mathrm{Sn} 3.8 \mathrm{Ag} 0.7 \mathrm{Cu}$ solders is improved obviously. With the addition of $0.03 \%$ to $0.05 \%$, the wetting time is about $0.7 \mathrm{~s}$ at $250^{\circ} \mathrm{C}$, which is very close to the $\mathrm{Sn}-\mathrm{Pb}$ solder. Moreover, in $\mathrm{N}_{2}$ atmosphere, the wetting behavior of $\mathrm{SnAgCu}$ solder is extremely improved. Due to the oxidation of molten solder and substrate is inhibited in $\mathrm{N}_{2}$ atmosphere. Furthermore, Zhao et al. [42] also found that the spreading area was increased with the increasing of the content of Ce. When the Ce addition is $0.1 \%$, the $\mathrm{Sn} 3.0 \mathrm{Ag} 2.8 \mathrm{Cu}-\mathrm{Ce}$ has the maximum spreading area of $242.80 \mathrm{~mm}^{2}$. However, as the content of Ce is over $0.1 \%$, the spreading areas will decrease.

In a word, the addition of rare earth elements can change the wetting behavior; there are two reasons leading to the result: in one aspect, rare earth is a surface-active element that can reduce the surface tension of liquid solder. In the other aspect, rare earth is liable to oxidation; thus the formation of excessive amount of oxide residue during soldering may deteriorate the wettability of the solder, thereby affecting the spreading properties [43].

Currently, with the advancement of nanotechnology through the years, more and more researchers try to add nanoparticles to improve the comprehensive performance of Sn-Ag-Cu lead-free solders.

The addition of $\mathrm{Mn}$ nanoparticles into $\mathrm{SnAgCu}$ solder worsens the wetting behavior. With the addition of $0.47 \mathrm{wt} . \%$ of Mn nanoparticles, the wetting angle of $\mathrm{SnAgCu}$ solder was 
increased from $10.71^{\circ}$ to $25.6^{\circ}$ and the spreading rate of the solder was also reduced from $88.9 \%$ to $77.4 \%$. It is caused by the increased viscosity for the addition of nanoparticles during soldering [18]. Tay et al. [44] found that the addition of $\mathrm{Ni}$ nanoparticles alters the wettability of $\mathrm{Sn} 3.8 \mathrm{Ag} 0.7 \mathrm{Cu}$ solder alloy. Results showed that the addition of $\mathrm{Ni}$ nanoparticles into $\mathrm{SnAgCu}$ solder leads to the wetting angle increasing from $19.3^{\circ}$ to $29.9^{\circ}$. For $\mathrm{Sn} 3.8 \mathrm{Ag} 0.7 \mathrm{Cu}$ solder bearing Co nanoparticles, the effect of Co nanoparticles on wettability was found by Yoon et al. [45]. With the Co nanoparticles addition concentration increasing, the wetting angle increased, and the spreading rate decreased. Similar effects were reported by Haseeb et al. [46, 47]. $\mathrm{Al}_{2} \mathrm{O}_{3}$ nanoparticles can significantly change the wetting behavior of $\mathrm{Sn} 3.5 \mathrm{Ag} 0.5 \mathrm{Cu}$ solder. The wetting angle of $\mathrm{SnAgCu}$ solder was decreased with the addition of $\mathrm{Al}_{2} \mathrm{O}_{3}$ nanoparticles; a minimum angle of $28.9^{\circ}$ can be found with $0.5 \%$ nano- $-\mathrm{Al}_{2} \mathrm{O}_{3}$ particles addition [20]. $\mathrm{Li}$ et al. [48] produced $\mathrm{Sn} 3.0 \mathrm{Ag} 0.5 \mathrm{Cu}$ solders by mechanically mixing $\mathrm{TiO}_{2}$ nanoparticles and pointed out that trace amount of $\mathrm{TiO}_{2}$ nanoparticles can effectively affect the wetting behavior of $\mathrm{Sn} 3.0 \mathrm{Ag} 0.5 \mathrm{Cu}$ solder. It is clear that the wetting time can be decreased by $53.7 \%$ and the wetting force can be increased by $37.6 \%$ with the addition of $0.25 \% \mathrm{TiO}_{2}$ particles. Liu et al. [49] studied the addition of graphene nanosheets (GNSs) into $\mathrm{Sn} 3.0 \mathrm{Ag} 0.5 \mathrm{Cu}$ solders using the powder metallurgy. The results show in SAC- $x$ GNS solder that, with GNSs addition content increasing, the contact angle was decreased. When the content of GNSs was $0.1 \%$, the contact angle can be decreased by $15.5 \%$. Nai et al. [50] investigated the effect of nonreactive and noncoarsening foreign enhancements on the wettability of $\mathrm{SnAgCu}$ solder. It is found that the wetting angles were reduced by $15.7 \%$ and $19.8 \%$ with the addition of $0.04 \%$ and $0.07 \%$ of carbon nanotubes (CNTs). Han et al. [51] also found that the addition of trace amount of Ni-coated carbon nanotubes (Ni-CNTs) did significantly improve the wettability of $\mathrm{SnAgCu}$ solder.

In conclusion, the addition of nanoparticles did not significantly affect the wettability of $\mathrm{SnAgCu}$ solders and may even deteriorate the wetting angles. However, according to Kripesh et al. [52], the wetting quality is considered as "very good" when the value is $0^{\circ}<\theta<20^{\circ}$. For the value $20^{\circ}<\theta<40^{\circ}$, it is considered as "good and acceptable." The wetting behavior is "bad" when $\theta>40^{\circ}$. Therefore, with the addition of nanoparticles, the wetting angle of $\mathrm{SnAgCu}$ composite solder is in the acceptable range. Moreover, different researchers obtained different result. It may be attributed to solder composition, soldering temperature, processing atmosphere, flux type, substrate metallurgy, and so on.

\section{Mechanical Properties}

The mechanical property is an important index to evaluate solder properties. It plays a vital role in the reliability of solder joints.

The effect of In element on the tensile strength of low$\mathrm{Ag} \mathrm{Sn} 0.3 \mathrm{Ag} 0.7 \mathrm{Cu}$ solder was studied by Kanlayasiri et al. [6]. With the $3.0 \mathrm{wt} . \%$ In added, the tensile strength of $\mathrm{SnAgCu}$ increases approximately by $79 \%$. The addition of $\mathrm{Ti}$ can
TABLE 1: Tensile strength of Sn3.5Ag0.7Cu- $x \mathrm{Sb}$ [55].

\begin{tabular}{lccc}
\hline Ageing time (h) & $\begin{array}{c}\text { SAC } \\
\text { UTS (MPa) }\end{array}$ & $\begin{array}{c}\text { SAC-0.8Sb } \\
\text { UTS (MPa) }\end{array}$ & $\begin{array}{c}\text { SAC-2.0Sb } \\
\text { UTS (MPa) }\end{array}$ \\
\hline 0 & 46.63 & 52.38 & 44.55 \\
200 & 39.73 & 47.62 & 45.97 \\
400 & 34.82 & 43.71 & 39.80 \\
600 & 33.09 & 45.29 & 36.05 \\
\hline
\end{tabular}

remarkably increase the mechanical properties of $\mathrm{SnAgCu}$ solder. However, with the addition of Ti being over $1.0 \mathrm{wt} . \%$, the mechanical properties of $S n 3.5 \mathrm{Ag} 0.5 \mathrm{Cu}$ were decreased due to the appearance of coarse $\mathrm{Ti}_{2} \mathrm{Sn}_{3}$ in the eutectic colonies [7]. Fe element can increase the shear strength of $\mathrm{SnAgCu}$ solder. Fallahi et al. [9] found that the shear strength of $\mathrm{Sn} 3.6 \mathrm{Ag} 0.9 \mathrm{Cu}$ solder was $29 \mathrm{Mpa}$; with the addition of $\mathrm{Fe}$ being $0.2 \mathrm{wt} . \%$ and $0.6 \mathrm{wt} . \%$, the shear strength was raised up to $40 \mathrm{MPa}$ and $53 \mathrm{MPa}$. When $0.8 \mathrm{wt} . \%$ of $\mathrm{Zn}$ was added to the $\mathrm{Sn} 3.8 \mathrm{Ag} 0.7 \mathrm{Cu}$ solder, the tensile force of $\mathrm{SnAgCu}$ solder joint can be improved by $10 \%$. With further increase of $\mathrm{Zn}$ content, the tensile force decreases evidently. It is attributed to the fact that $\mathrm{Zn}$ has stronger affinity for oxygen, and an excessive amount of $\mathrm{Zn}$ addition will form superfluous $\mathrm{Zn}$ oxides. Therefore, the mechanical properties of $\mathrm{SnAgCu}-x \mathrm{Zn}$ solder joints were decreased [27]. The similar strengthening effect of $\mathrm{Zn}$ on the tensile strength of $\mathrm{SnAgCu}$ was also found by Song et al. [53]. Bi element can also improve the mechanical properties of $\mathrm{SnAgCu}$ solder. When the addition of Bi was $2.0 \mathrm{wt} . \%$, an improvement of $47 \%$ of the ultimate tensile strength (UTS) was achieved. When the addition of Bi was $4.0 \mathrm{wt} . \%$, the UTS was almost 2 times that of $\mathrm{SnAgCu}$ solder [12]. Ni can enhance the mechanical properties of Sn2.0Ag0.5Cu solder, which was studied by El-Daly and ElTaher [54]. It is found that the ultimate tensile strength (UTS) and yield strength (YS) both increased with the increasing amount of Ni. The tensile strength of $\mathrm{SnAgCu}$ solder joint bearing $\mathrm{Sb}$ was investigated by $\mathrm{Li}$ et al. [55], as shown in Table 1. Results showed that the addition of Sb can obviously improve the tensile strength of $\mathrm{SnAgCu}$ solder alloys and joints during the ageing time. The reason could be attributed to solid solution hardening and particle hardening. Luo et al. [30] reported that the shear strength of $\mathrm{Sn} 0.5 \mathrm{Ag} 0.7 \mathrm{Cu}$ solder joint can be improved with the addition of Ga. When the addition of $\mathrm{Ga}$ was up to $0.5 \mathrm{wt} . \%$, shear strength gives a $17.9 \%$ increase.

Adding an appropriate amount of rare earth elements mainly containing $\mathrm{Ce}$ and La elements can remarkably increase the mechanical properties of $\mathrm{SnAgCu}$ solder [34], as shown in Figure 4. Moreover, with the increasing of Ag, the tensile strength is also improved. The strength of Sn3.8Ag0.7Cu solder joint was improved with $\mathrm{Y}$ addition. However, when the $\mathrm{Y}$ content exceeds $0.15 \mathrm{wt} . \%$, the strength of joint has a dramatical decrease [36]. With the addition of $\mathrm{Er}$, the shear strength of $\mathrm{Sn} 3.8 \mathrm{Ag} 0.7 \mathrm{Cu}$ solder was improved significantly. When the Er addition is up to $0.1 \mathrm{wt} . \%$, given a $18 \%$ increase compared with $\mathrm{SnAgCu}$ solder [37]. The mechanical properties of $\mathrm{Sn} 3.8 \mathrm{Ag} 0.7 \mathrm{Cu}$ solder joint bearing 


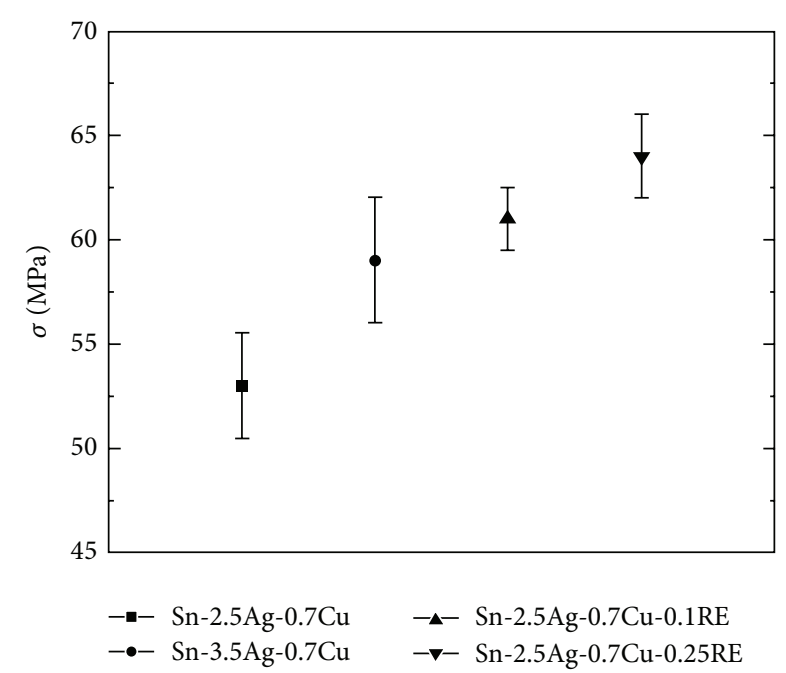

FIgURE 4: Tensile properties of SAC-RE [34].

Pr was studied by Gao et al. [38]. Both the pull force and shear force were gradually increased with the increase of Pr content. When the Pr addition is up to 0.05 wt.\%, these samples showed $18.5 \%$ and $19.4 \%$ higher on the pull force and shear force, respectively. However, when the Pr content was over $0.25 \mathrm{wt} . \%$, the results showed a sharp decline in the strength of $\mathrm{SnAgCu}$ solder. The simple enhancement effect was found in $\mathrm{SnAgCu}$ bearing Nd; the pull force and shear force of the solder joint give $19.4 \%$ and $23.6 \%$ increase [39]. As a surface-active element, rare earth $\mathrm{Yb}$ can also improve the tensile strength of Sn3.8Ag0.7Cu solder joints in QFP devices. When the $\mathrm{Yb}$ content was up to $0.05 \mathrm{wt} . \%$, the tensile force was increased by $25.4 \%$ [40].

The addition of Fe microparticles to the $\mathrm{SnAgCu}$ solder paste was investigated by Yan et al. [56]. It is found that, by the addition of $1.0 \mathrm{wt} . \%$ Fe micoparticles, the shear strength of $\mathrm{SnAgCu}$ solder can be improved by 39\%. Gain et al. [57] develop a series of $\mathrm{Sn} 3.5 \mathrm{Ag} 0.5 \mathrm{Cu}$ composite solders reinforced with different weight percentages $(0,0.5,1$, and 3 wt.\%) of Al nanoparticles. The Sn3.5Ag0.5Cu composites solder joints containing $3 \mathrm{wt}$.\% Al nanoparticles consistently displayed a higher shear strength than that of original SnAgCu solder joints and a low Al nanoparticles content as a function of reflow cycles and aging time because of a second phase dispersion strengthening mechanism by the formation of fine Sn-Ag-Al IMC as well as a controlled fine microstructure. Tsao et al. [58] studied the effects of $\mathrm{Al}_{2} \mathrm{O}_{3}$ doping on the properties of $\mathrm{Sn} 3.5 \mathrm{Ag} 0.5 \mathrm{Cu}$ solders. They found that, by the addition of $1 \mathrm{wt} . \% \mathrm{Al}_{2} \mathrm{O}_{3}$, the shear strengths increased by $14.4 \%$ and $16.5 \%$ after 1 cycle and 8 cycles of reflow. $\mathrm{TiO}_{2}$ nanoparticles can improve the tensile strength of $\mathrm{Sn} 3.0 \mathrm{Ag} 0.5 \mathrm{Cu}$ solder. When the $\mathrm{TiO}_{2}$ nanoparticles content was $0.1 \mathrm{wt} . \%$, the tensile strength can be enhanced from $48.7 \mathrm{MPa}$ to $53.2 \mathrm{MPa}$ [59]. Roshanghias et al. [60] revealed that the $0.2 \%$ yield stress and UTS both increased with addition of $\mathrm{CeO}_{2}$ nanoparticles. It is mainly attributed to the presence of $\mathrm{CeO}_{2}$ nanoparticles in the
Sn3.5Ag0.7Cu solder matrix acting as obstacles for dislocation motion resulting in enhancement in the applied stress required to move dislocations. $\mathrm{TiB}_{2}$ nanoparticles can also enhance the mechanical properties of $\mathrm{SnAgCu}$ solder; when the addition of $\mathrm{TiB}_{2}$ was $3 \mathrm{vol} . \%$, an improvement of $23 \%$ for UTS and 26\% for YS was observed [61]. Yang et al. [62] found that the addition of $0.05 \mathrm{wt} . \%$ Ni-coated carbon nanotubes (Ni-CNTs) can improve the tensile strength of $\mathrm{SnAgCu}$ solder slabs and joints. It is due to CNTs as reinforcements act as an obstacle to suppress the initiation of dislocation motion in the $\mathrm{SnAgCu}$ solder matrix. Kumar et al. [63] also reported that the addition of single-wall carbon nanotube (SWCNT) can improve the mechanical properties of $\mathrm{Sn} 3.8 \mathrm{Ag} 0.7 \mathrm{Cu}$ solder. Results showed that the ultimate tensile strength of SAC-1.0SWCNT was about 50\% higher than that of the plain $\mathrm{SnAgCu}$ solder. The addition of graphene nanosheets (GNSs) can improve the tensility of Sn-Ag-Cu solder. With the content of $0.03 \mathrm{wt} . \%$ GNS, the ultimate tensile strength was increased approximately $10 \%$ [49].

In a word, the addition of alloying elements and nanoparticles can significantly enhance the mechanical properties and improve the reliability of $\mathrm{SnAgCu}$ solder. However, when the addition is excessive, the negative effect can be found obviously. It is attributed to the characteristic of the material. For example, an excessive amount of rare earth addition will form superfluous RE-oxides, which will degrade the mechanical properties of the solder joint. For the nanocomposite solder, the addition of nanoparticles can act as nucleation in the molten solder, thus improving the mechanical properties. But too much addition can reduce the mechanical properties, which can be attributed to the agglomeration of nanoparticles. Therefore, selecting the appropriate content is very important.

\section{Hardness Properties}

The measurement of hardness, especially Vickers microhardness, is a usual method to characterize the mechanical properties of solder. The microhardness of the solder is often connected with how the metallic material resists wearing or abrasion. It also determines the applicability under various circumstances [64].

Adding In element to the $\mathrm{SnAgCu}$ solder will affect its microhardness by changing its microstructure. When the addition of In was $3.0 \mathrm{wt} . \%$, the microhardness of Sn0.3Ag0.7Cu solder was increased by $81 \%$ [6]. The addition of $\mathrm{Ni}$ and $\mathrm{Zn}$ into $\mathrm{Sn} 2.0 \mathrm{Ag} 0.5 \mathrm{Cu}$ solder was reported by ElDaly and El-Taher [54]. It is found that the microhardness of SAC- $0.05 \mathrm{Ni}$ and SAC-0.5Zn solders was increased to 12.2 and $12.6 \mathrm{Hv}$, respectively, as compared with $11.4 \mathrm{Hv}$ of Sn-Ag$\mathrm{Cu}$ solder. Lin et al. [8] investigated the effects of Ti and Mn addition on hardness of $\mathrm{Sn}-\mathrm{Ag}-\mathrm{Cu}$ solder alloy, as shown in Figure 5. The experimental results indicated that the hardness values of $\mathrm{Ti}_{2} \mathrm{Sn}_{3}$ and $\mathrm{MnSn}_{2}$ were $9.1 \pm 0.2$ and $8.9 \pm 0.1 \mathrm{GPa}$. Moreover, the Young's moduli determined from nanoindentation experiments were as follows: $151.7 \pm 2 \mathrm{GPa}$ for $\mathrm{Ti}_{2} \mathrm{Sn}_{3}$ and $143.9 \pm 1 \mathrm{GPa}$ for $\mathrm{MnSn}_{2}$. The intermetallic compounds induced by alloying elements were obviously harder and stiffer than $\mathrm{Cu}_{6} \mathrm{Sn}_{5}$ and $\mathrm{Ag}_{3} \mathrm{Sn}$. Therefore, enhanced hardness 


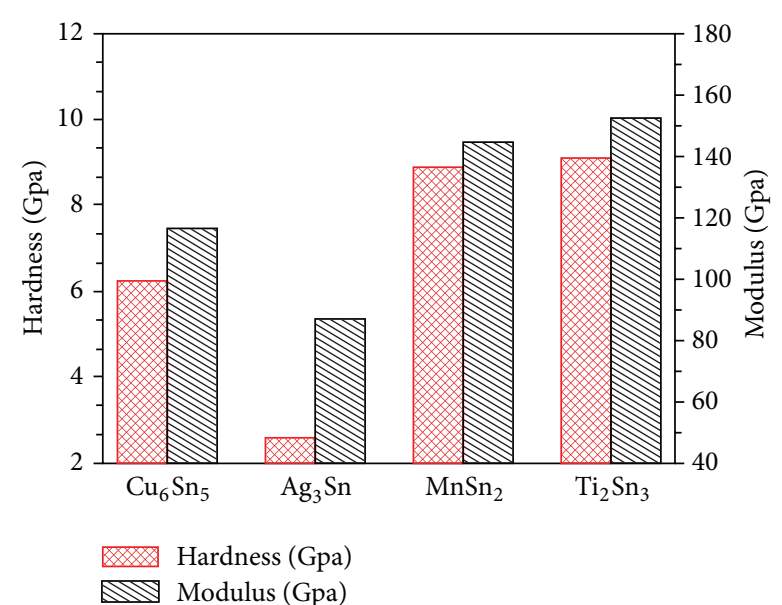

FIGURE 5: Nanoindentation results of the intermetallic phases [8].

of $\mathrm{SnAgCu}$ solder was achieved in this trial by adding $\mathrm{Ti}$ and $\mathrm{Mn}$. The rare earth La can also influence the microhardness of Sn3.0Ag0.5Cu solder, which was investigated by Zhou et al. [65]. With the addition of La, the microhardness of $\beta$-Sn and eutectic area was enhanced from 13.8 to $16.4 \mathrm{Hv}$ and from 16.8 to $18.8 \mathrm{Hv}$, respectively. With the $\mathrm{Al}$ and $\mathrm{Ni}$ nanoparticles addition, the hardness of $\mathrm{SnAgCu}$ solder can also be improved [66]. The addition of $\mathrm{Cu}, \mathrm{Ni}$, and $\mathrm{Mo}$ nanoparticles

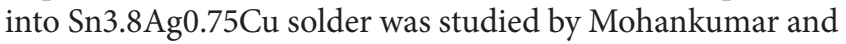
Tay [67]. The results showed that, with $\mathrm{Cu}, \mathrm{Ni}$, and $\mathrm{Mo}$ addition concentration increasing, hardness was enhanced. Meanwhile, it is also found that the Mo nanoparticles increase the hardness value apparently higher than $\mathrm{Ni}$ and $\mathrm{Cu}$. The hardness values of $\mathrm{SnAgCu}$ composite solders follow a trend with $\mathrm{Mo}>\mathrm{Ni}>\mathrm{Cu}$. The amount of $\mathrm{Al}_{2} \mathrm{O}_{3}$ nanoparticles can enhance the microhardness of $\mathrm{Sn} 3.5 \mathrm{Ag} 0.5 \mathrm{Cu}$ solder and increase the range of from $8.5 \%$ to $52.3 \%$ [20]. The $\mathrm{CeO}_{2}$ nanoparticles can alter the microhardness value of $\mathrm{Sn} 3.5 \mathrm{Ag} 0.7 \mathrm{Cu}$ composite solders. It is found that the increase of the amount of $\mathrm{CeO}_{2}$ can increase the microhardness value [60]. The researchers attributed this to the presence of hard $\mathrm{CeO}_{2}$ nanoparticles reinforcement in the solder matrix as well as higher constraint to the localized matrix deformation. The Sn3.8Ag0.7Cu solder containing 0.05 wt. \% $\mathrm{SiC}$ nanoparticles can increase the microhardness by $44 \%$ compare with the plain solder [19]. The microhardness of Sn3.0Ag0.5Cu bearing POSS molecules was studied by Shen et al. [68]. The microhardness increased with the increase amount of POSS molecules. Furthermore, with the addition of $5 \mathrm{wt} . \%$ POSS, the microhardness of $\mathrm{SnAgCu}$ solder was reduced, which can be attributed to the agglomeration of POSS molecules and the appearance of a coarse lath-shaped structure in solder matrix.

\section{Microstructures}

Material properties depend on the microstructure. The typical microstructures of $\mathrm{SnAgCu}$ lead-free solder alloys are made up of primary $\beta$-Sn grains, platelet-type $\mathrm{Ag}_{3} \mathrm{Sn}$, and

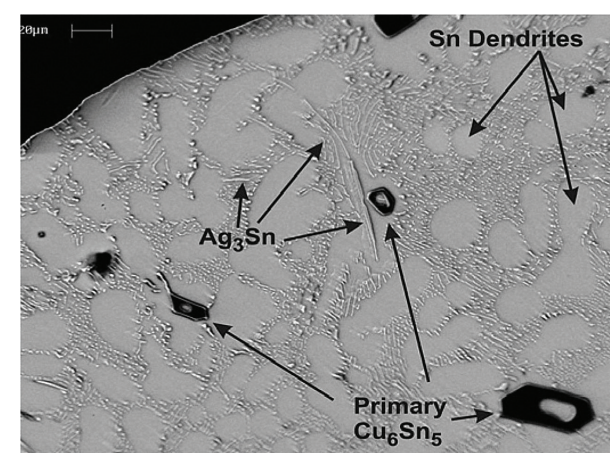

Figure 6: The microstructure of SnAgCu solder [69].

scallop-type $\mathrm{Cu}_{6} \mathrm{Sn}_{5}$ [69] (Figure 6). According to a dispersion strengthening mechanism, uniform microstructure has positive effects on the enhanced mechanical properties of the solder joint.

Kanlayasiri et al. [6] have found that, by the addition of In into $\mathrm{SnAgCu}$ solders, the Sn-rich phase and the intermetallic compounds become much finer and more uniform. Ti element can change the microstructure of $\mathrm{Sn} 3.5 \mathrm{Ag} 0.5 \mathrm{Cu}$ solder. With the addition of $1.0 \mathrm{wt} . \% \mathrm{Ti}$, the grain size of $\beta$-Sn was about $4.8 \pm 1.7 \mu \mathrm{m}$, and the width of the eutectic area was $1.2 \pm 0.4 \mu \mathrm{m}$, as compared with $24.8 \pm$ $5.9 \mu \mathrm{m}$ and $6.8 \pm 2.8 \mu \mathrm{m}$ for the $\mathrm{Sn} 3.5 \mathrm{Ag} 0.5 \mathrm{Cu}$ solder. It was attributed to the unique properties of active element $\mathrm{Ti}$, which can enhance appearance of heterogeneous intermetallic compounds and a morphological change of IMC [7]. Shnawah et al. [70] compared the Sn3.0Ag0.5Cu solder with $\mathrm{Sn} 1.0 \mathrm{Ag} 0.5 \mathrm{Cu}$ solder and found that the $\mathrm{Sn} 3.0 \mathrm{Ag} 0.5 \mathrm{Cu}$ has smaller primary $\beta$-Sn dendrites and wider interdendritic regions than $\mathrm{Sn} 1.0 \mathrm{Ag} 0.5 \mathrm{Cu}$. In addition, with the addition of Fe element, a large $\mathrm{FeSn}_{2}$ intermetallic compound was formed and caused a weak interface with the $\beta$-Sn matrix. Trace amount of $\mathrm{Mg}$ into $\mathrm{SnAgCu}$ solder will cause the eutectic phases to become coarsened, and the fraction of eutectic microstructure will decrease [32]. The addition of $\mathrm{Al}$ can change the microstructure of $\mathrm{Sn} 1.0 \mathrm{Ag} 0.5 \mathrm{Cu}$ solder. Results showed that the primary $\beta$-Sn dendrites were refined and the interdendritic regions were enlarged. Moreover, the formation of $\mathrm{Ag}_{3} \mathrm{Sn}$ and $\mathrm{Cu}_{6} \mathrm{Sn}_{5}$ intermetallic compounds was suppressed. And the $\mathrm{Ag}_{3} \mathrm{Al}$ and $\mathrm{Al}_{2} \mathrm{Cu}$ intermetallic compounds were found [71]. Zhang et al. [27] in their study on $\mathrm{Zn}$-doped $\mathrm{SnAgCu}$ solder found that $\mathrm{Zn}$ can significantly refine the dendrite $\beta$-Sn and when the $\mathrm{Zn}$ was $0.8 \%$, the dispersed $\mathrm{Cu}-\mathrm{Zn}$ intermetallic compounds was formed. The microstructure and mechanical properties of low Ag-content Sn0.5Ag0.7Cu solder doped with $\mathrm{Ni}$ element have been investigated by Hammad [72]. It is found that adding $0.05 \mathrm{Ni}$ can refine the microstructure of $\mathrm{Sn} 0.5 \mathrm{Ag} 0.7 \mathrm{Cu}$ solder and can reduce the sizes of $\mathrm{Sn}$-rich phase. Meanwhile, the $\mathrm{Ag}_{3} \mathrm{Sn}$ and $(\mathrm{Cu}, \mathrm{Ni})_{6} \mathrm{Sn}_{5}$ intermetallic compounds were uniformly distributed in the Sn matrix. However, the addition of $0.1 \mathrm{Ni}$ into $\mathrm{Sn} 0.5 \mathrm{Ag} 0.7 \mathrm{Cu}$ solder cause the formation of relatively high fraction of the primary $\beta$-Sn and the intermetallic compounds appeared abrasive within the matrix. El-Daly

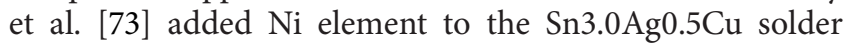




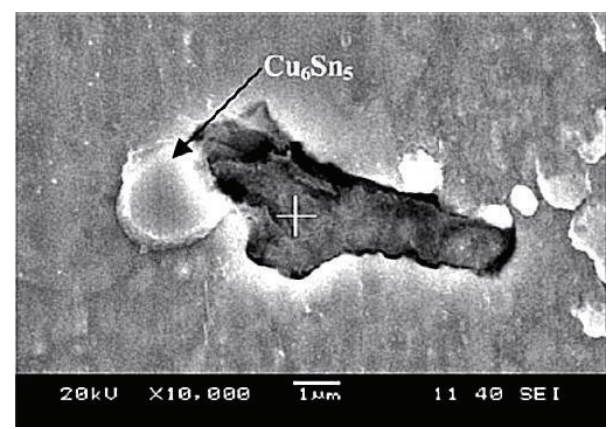

Figure 7: Sn-Nd phase [39].

alloy and observed a similar phenomenon. Chen and $\mathrm{Li}$ [74] reported that the addition of $\mathrm{Sb}$ into $\mathrm{SnAgCu}$ solder can obviously improve the microstructure and properties of lead-free solder. It was indicated that some of the Sb powders were fused in the $\beta$-Sn matrix ( $\mathrm{Sn}$-rich phase); some of them participate in the form of $\mathrm{Ag}_{3}(\mathrm{Sn}, \mathrm{Sb})$, and the rest fused in the $\mathrm{Cu}_{6} \mathrm{Sn}_{5}$ IMC layer. With the addition of $\mathrm{Sb}$, both thickness and grain size of IMC were decreased. Furthermore, the results reveal that $\mathrm{Sn} 3.5 \mathrm{Ag} 0.7 \mathrm{Cu}$ with about 1.0 wt.\% Sb solder system exhibited the smallest growth rate and gives the most prominent effect in retarding IMC growth and refining IMC grain size. It is due to Sb element has higher affinity to $\mathrm{Sn}$, and it will reduce the activity of $\mathrm{Sn}$ by forming $\mathrm{Sn}$-Sb compound, leading to a reduced driving force for $\mathrm{Cu}-$ Sn IMC formation. A heterogeneous nucleation effect for restricting the IMC growth due to Sb addition is proposed.

In general, trace rare earth addition had little influence on the melting temperature but can remarkably refine the microstructures of SnAgCu lead-free solders. Law et al. [35] noted that, by adding RE into Sn3.8Ag0.7Cu solder, the grain size of $\beta$-Sn phases was refined and reduced to about $5-10 \mu \mathrm{m}$, respectively, as compared with $10-20 \mu \mathrm{m}$ of $\mathrm{Sn} 3.8 \mathrm{Ag} 0.7 \mathrm{Cu}$ solder. It is mainly because RE is active elements, which can accumulate the interface of intermetallic particles [75]. Therefore, the addition RE elements affect the microstructure of $\mathrm{SnAgCu}$ solder. Nevertheless, the addition of an excessive amount of RE elements would cause the appearance of a large number of the RE compounds, whose the shape is similar to a "snowflake" [76]. Shi et al. [37] studied the influence of rare earth Er on the microstructure and property of $\mathrm{SnAgCu}$ solder and found that addition of $0.25 \mathrm{Er}$ into $\mathrm{Sn} 3.8 \mathrm{Ag} 0.7 \mathrm{Cu}$ reduces the size of $\mathrm{Ag}_{3} \mathrm{Sn}$ and $\mathrm{Cu}_{6} \mathrm{Sn}_{5}$ intermetallic compounds particles. The addition of $\mathrm{Pr}$ and $\mathrm{Nd}$ has a significant effect on the microstructure of $\mathrm{SnAgCu}$ solder. The $\beta$-Sn dendrites and the intermetallic compounds growth were refined. Meanwhile, with the change of rare earth content, the microstructures of $\mathrm{SnAgCu}-x \operatorname{Pr}(\mathrm{Nd})$ solders change. The reason is attributed to $\mathrm{Pr}$ and $\mathrm{Nd}$ atoms tending to react with $\mathrm{Sn}$ atoms to form $\mathrm{RESn}_{3}$ compound (Figure 7) and uniformly dispersed fine $\mathrm{RESn}_{3}$ particles can act as heterogeneous nucleation sites for solidification. Furthermore, the $\mathrm{Cu}_{6} \mathrm{Sn}_{5}$ and $\mathrm{Ag}_{3} \mathrm{Sn}$ phase growth attaches to primary $\mathrm{RESn}_{3}$ phase; thus the microstructure of $\mathrm{SnAgCu}$ solder becomes finer. However, an excessive amount of RE added can form bulk
$\mathrm{RESn}_{3}$ phase and deteriorate the mechanical properties of SnAgCu solder joint [38, 39]. Zhang et al. [40] added $0.05 \mathrm{Yb}$ to the Sn3.8Ag0.7Cu solder and observed that the sizes of $\mathrm{Sn}$ and eutectic microstructures were obviously reduced to become finer particles and the eutectic phase further spread to form network areas. It is due to the absorption of $\mathrm{Yb}$ with a high surface free energy on the grains during solidification during solidification. However, when adding $\mathrm{Yb}$ to $0.1 \%$, the microstructure will become coarser than that of Sn3.8Ag0.7Cu0.05Yb. Moreover, the Sn-Yb particles can be observed based on scanning electron microscopy (SEM) testing. Dudek and Chawla [17] investigated the microstructure and mechanical behavior effects of adding La, Ce, and Y to the Sn3.9Ag0.7Cu solder. It is found that the addition of $\mathrm{La}$, $\mathrm{Ce}$, and $\mathrm{Y}$ into $\mathrm{SnAgCu}$ solder can refine the microstructures and reduced the thickness of the intermetallic compounds of SnAgCu solder. With a further increasing RE content, the $\mathrm{LaSn}_{3}, \mathrm{CeSn}_{3}$, and $\mathrm{YSn}_{3}$ intermetallic compounds formed.

Gain and Chan [66] found that the incorporation of $\mathrm{Al}$ and $\mathrm{Ni}$ nanoparticles suppressed the formation of $\mathrm{Cu}_{3} \mathrm{Sn}$ IMC layer and refined IMC grains. The possible reason could be attributed to very fine $\mathrm{Sn}-\mathrm{Ni}-\mathrm{Cu} \mathrm{IMC}$ and $\mathrm{Sn}-\mathrm{Ag}-\mathrm{Al}$ IMC particles, respectively, in the $\mathrm{SnAgCu}-0.5 \mathrm{Ni}$ solder and $\mathrm{SnAgCu}-0.5 \mathrm{Al}$ solder joints. Moreover, they were uniformly distributed in the $\beta$-Sn matrix. Zhang et al. [77] also have reported that the addition of $\mathrm{Al}$ nanoparticles into $\mathrm{SnAgCu}$ composite solder can decrease the average size of IMCs and the spacing between them obviously. The addition of small percentage of Fe microparticle into $\mathrm{Sn} 3.0 \mathrm{Ag} 0.5 \mathrm{Cu}$ solder alloy had a change on the microstructure of solder joint. Clearly, the microstructure was refined and the $\mathrm{FeSn}_{2}$ phase was appeared. With the addition of $\mathrm{Al}_{2} \mathrm{O}_{3}$ nanoparticles can influence the microstructure of $\mathrm{SnAgCu}$ solder ball. Figure 8 shows that the volume fraction of the eutectic colony was broader and $\mathrm{Ag}_{3} \mathrm{Sn}$ was refined [58]. It is due to the adsorption effect and high surface free energy of the $\mathrm{Al}_{2} \mathrm{O}_{3}$ nanoparticles on the grain surface during solidification process [20]. Tang et al. [59] reported that the addition of trace amount $\mathrm{TiO}_{2}$ nanoparticles can influence the microstructure of $\mathrm{Sn} 3.0 \mathrm{Ag} 0.5 \mathrm{Cu}$ solder, and the size and spacing of $\mathrm{Ag}_{3} \mathrm{Sn}$ decrease significantly. When the content of $\mathrm{TiO}_{2}$ nanoparticles was $0.1 \mathrm{wt} . \%$, the $\mathrm{Ag}_{3} \mathrm{Sn}$ grains size and spacing were decreased by $57.76 \%$ and $52.31 \%$. With a further increase of $\mathrm{TiO}_{2}$ addition, the microstructure was similar to $\mathrm{TiO}_{2}$-free noncomposite solder matrix. It was attributed to the agglomeration and segregation of $\mathrm{TiO}_{2}$ nanoparticles in the solders, because the van der Waals forces caused $\mathrm{TiO}_{2}$ nanoparticles to become entangled with each other as they approached about $0.1 \mathrm{wt} . \%$; therefore, the $\mathrm{Ag}_{3} \mathrm{Sn}$ grains size will not decrease more. Liu et al. [19] developed the Sn3.8Ag0.7 Cu solder bearing $\mathrm{SiC}$ nanoparticles. It can be seen that the growth and size of the IMCs in the composite solder matrix decrease significantly. However, when the content of $\mathrm{SiC}$ nanoparticles was $0.2 \mathrm{wt} . \%$, the IMCs size did not decrease. For the addition of $\mathrm{SrTiO}_{3}$ nanoparticles into $\mathrm{Sn3} .0 \mathrm{Ag} 0.5 \mathrm{Cu}$ solder, very fine needle-shaped $\mathrm{Ag}_{3} \mathrm{Sn}$, spherical-shape $\mathrm{Cu}_{6} \mathrm{Sn}_{5}$ and $\mathrm{AuSn}_{4}$ IMCs were found in the solder matrix. The reason might be explained by the second phase reinforcement $\mathrm{SrTiO}_{3}$ nanoparticles and promoted 

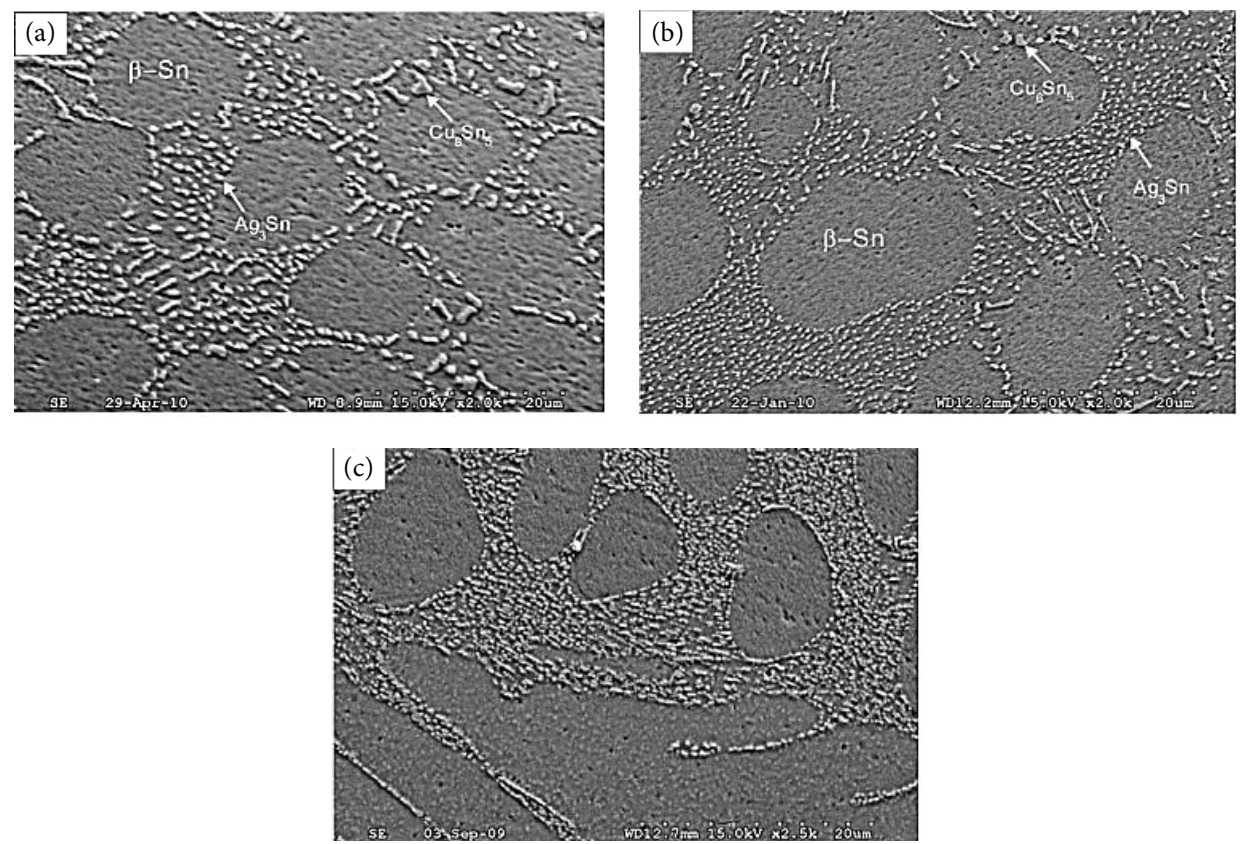

Figure 8: (a) SAC, (b) SAC-0.5 $\mathrm{Al}_{2} \mathrm{O}_{3}$, and (c) $\mathrm{SAC}-1.0 \mathrm{Al}_{2} \mathrm{O}_{3}$ [58].

a high nucleation rate in the eutectic during solidification [78]. Fawzy et al. [23] investigated the effect of $\mathrm{ZnO}$ nanoparticles on the microstructure of $\mathrm{Sn} 3.5 \mathrm{Ag} 0.5 \mathrm{Cu}$ solder. After adding $\mathrm{ZnO}$ nanoparticles, the volume fraction of $\mathrm{Ag}_{3} \mathrm{Sn}$ and $\mathrm{Cu}_{6} \mathrm{Sn}_{5}$ IMCs was suppressed; meanwhile, the $\beta$-Sn grain size was reduced by $22 \%$. The effects of addition $\mathrm{ZrO}_{2}$ nanoparticles on the microstructure of $\mathrm{SnAgCu}$ solder on $\mathrm{Au} / \mathrm{Ni}$ metallized $\mathrm{Cu}$ pads were investigated by Gain et al. [79]. A $\mathrm{Sn}-\mathrm{Ni}-\mathrm{Cu}$ IMC layer was found in both $\mathrm{SnAgCu}$ plain solder and $\mathrm{SnAgCu}-\mathrm{ZrO}_{2}$ solder, and with the number of reflow cycles, the IMC layer thickness was increased. As the content of $\mathrm{ZrO}_{2}$ nanoparticles increased, $\mathrm{AuSn}_{4}, \mathrm{Ag}_{3} \mathrm{Sn}$, and $\mathrm{Cu}_{6} \mathrm{Sn}_{5}$ IMC particles and $\mathrm{ZrO}_{2}$ nanoparticles were homogeneously distributed in the solder matrix. Therefore, adding a small amount of $\mathrm{ZrO}_{2}$ nanoparticles refined the microstructure of the composite solder. Adding POSS molecules to the Sn3.0Ag0.5Cu composite solder can decrease the grains sizes and space lengths of $\mathrm{Ag}_{3} \mathrm{Sn}$ IMCs. As the POSS content increases further, the microstructure of $\mathrm{SnAgCu}$ solder has no significant change [68]. The graphene nanosheets (GNSs) as the additive into $\mathrm{SnAgCu}$ solder can restrict the grain growth and lead to finer IMC grains. With the addition of $0.03 \%$, $0.07 \%$, and $0.10 \% \mathrm{GNS}$, the average size of the IMCs was reduced to $1.35 \mu \mathrm{m}, 1.24 \mu \mathrm{m}$, and $1.21 \mu \mathrm{m}$, as compared with $1.96 \mu \mathrm{m}$ for the Sn3Ag0.5Cu solder [49]. For SAC-SWCNT composite solders, with increasing SWCNT additive, the average size/morphology of the secondary phase was sharply reduced [63]. Due to CNT being a ceramic material, the surface diffusion of the $\mathrm{Ag}_{3} \mathrm{Sn}$ can be suppressed by the exceedingly quicker translations of ceramic materials through the temperatures that are produced while the sintering reaction takes place [80]. Han et al. [51] and Yang et al. [62] also have reported the influence of $\mathrm{Ni}$-coated carbon addition on the microstructure of $\mathrm{Sn} 3.5 \mathrm{Ag} 0.7 \mathrm{Cu}$ nanocomposite solder. It is found that the morphology of $\mathrm{Ag}_{3} \mathrm{Sn}$ and $\mathrm{Cu}_{6} \mathrm{Sn}_{5}$ was uniformly distributed in the solder matrix.

In short, the addition of the fourth elements can significantly change the microstructure of $\mathrm{SnAgCu}$ solders. However, their principles are different. Some researchers by adding alloy elements produced the intermetallic compounds, which alloying elements react with $\mathrm{Sn}$, thus refining the microstructure of $\mathrm{SnAgCu}$ solder. Other researchers choose to add some low solubility and diffusivity in $\mathrm{Sn}$, such as $\mathrm{Al}_{2} \mathrm{O}_{3}, \mathrm{TiO}_{2}, \mathrm{SiC}$, and POSS. Meanwhile, we also found that the addition of elements has a critical value, When more than a critical value will cause harm to the properties of solder joint.

\section{Interfacial Reactions}

Interfacial reaction is solder/substrate systems which are of particular importance to the manufacturability and reliability of electronic packaging [81]. During soldering, the solder alloys react with the substrate to form intermetallic compounds (IMCs) at the interface [82], such as $\mathrm{Cu}_{6} \mathrm{Sn}_{5}, \mathrm{Cu}_{3} \mathrm{Sn}$, and other IMCs. Figure 9 shows the IMC layers formed between the solder and substrate after soldering [83]. It is well known that a thin IMC layer is desirable to achieve a good metallurgical bound at the interface. However, excessive IMC growth may have a detrimental effect due to the brittle nature of IMC [84]. Therefore, knowledge of the morphology, growth behavior, and properties of IMC is crucial for understanding of the reliability of the solder interconnection.

The formation of IMC is divided into two stages: one stage which is $\mathrm{Cu}_{6} \mathrm{Sn}_{5}$ forms first at the interface during soldering, and the other which is $\mathrm{Cu}_{3} \mathrm{Sn}$ will form between $\mathrm{Cu}_{6} \mathrm{Sn}_{5}$ 


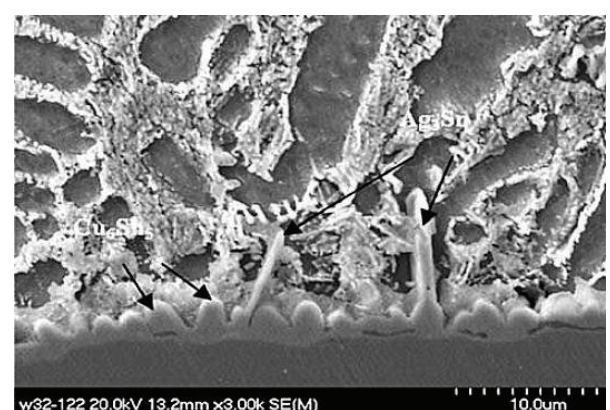

FIgURE 9: The microstructure of IMC layer at the interface between solder and copper [83].

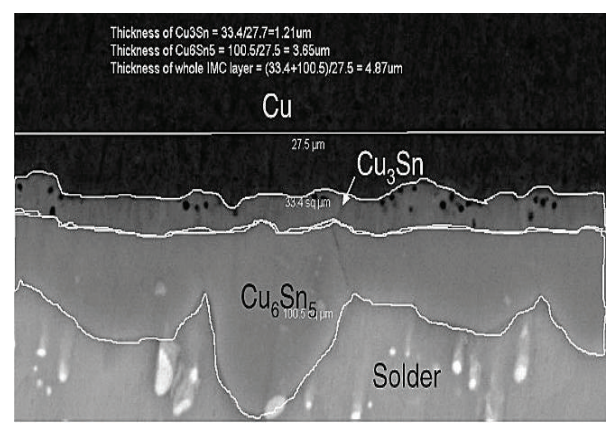

FIgUre 10: The sample was aged at $150^{\circ} \mathrm{C}$ for $100 \mathrm{~h} . \mathrm{Cu}_{6} \mathrm{Sn}_{5}$ had scallop-like shape and $\mathrm{Cu}_{3} \mathrm{Sn}$ is more of layer type [85].

and $\mathrm{Cu}$ by solid-stage reaction and the Kirkendall voids were observed in the $\mathrm{Cu}_{3} \mathrm{Sn}$ layer (Figure 10), which is attributed to the faster diffusion of $\mathrm{Cu}$ atoms compared to that of $\mathrm{Sn}$ atoms through the interface [85].

From the brief review, we will find how to suppress the growth of IMC. Some researchers study only the liquid-stage, and some study the solid-stage, while others study both.

Below, we shall review that the addition of the fourth alloys into SnAgCu lead-free solders influences the interfacial microstructure.

The effect of solid state reactions between Sn3.0Ag0.4Cu7.0In composite solder and $\mathrm{Cu}$ substrate was studied by Lejuste et al. [86]. The experimental results showed that two IMCs layers, $\mathrm{Cu}_{6}(\mathrm{Sn}, \mathrm{In})_{5}$ and $\mathrm{Cu}_{3}(\mathrm{Sn}, \mathrm{In})$, were formed at the interface. Meanwhile, they found that the growth coefficients of $\mathrm{Cu}_{6}(\mathrm{Sn}, \mathrm{In})_{5}$ layer were similar to those of plain $\mathrm{SnAgCu}$ solders, while the growth coefficients of $\mathrm{Cu}_{3}(\mathrm{Sn}$, In) layer were found to be clearly lower than those for the $\mathrm{SnAgCu}$ solders. Therefore, it is indicated that the addition of In element can suppress the growth of IMC layer during thermal aging. The $0.8 \% \mathrm{Zn}$ addition into

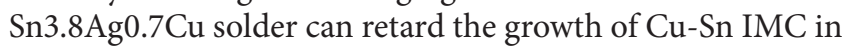
liquid/solid state reaction and analyzes the reasons resulting in this situation. It is mainly caused by an accumulation of $\mathrm{Zn}$ atoms at the interface [27]. Wang et al. [87] also found that the growth of IMC was significantly reduced by the $0.2 \% \mathrm{Zn}$ addition into $\mathrm{SnAgCu}$ solder. The addition of $1 \mathrm{wt} . \% \mathrm{Bi}$ into Sn2.8Ag0.5Cu solder was studied by Rizvi et al. [28], showing that $1 \mathrm{wt} . \% \mathrm{Bi}$ addition could restrict the excessive formation of IMC during the soldering reaction and thereafter in aging condition. After a few days of aging, the morphology of the IMC layer between the SnAgCu-Bi solder and the $\mathrm{Cu}$ substrate transformed from the scallop type to the planar type, and the intermetallic growth rate of $\mathrm{SnAgCu}-\mathrm{Bi}$ was calculated as $1.91 \times 10^{17} \mathrm{~m}^{2} / \mathrm{s}$ compared with $2.21 \times 10^{17} \mathrm{~m}^{2} / \mathrm{s}$ for the $\mathrm{SnAgCu}$ solder. Adding a small amount of Ni alloying to the $\mathrm{Sn3} .0 \mathrm{Ag} 0.5 \mathrm{Cu}(\mathrm{SAC})$ solder can also reduce the IMC layer thickness. Comparing the SAC-Ni with the SAC, it was found that the IMC thickness of SAC-Ni composite solder exhibits a slight change after aging, whereas the IMC thickness of SAC was markedly increased by approximately $60 \%$ compared to that at the as-reflowed state [15]. Chen and $\mathrm{Li}$ [74] proposed that adding $\mathrm{Sb}$ can also restrain the IMC growth because of the formation of $\mathrm{Sn}-\mathrm{Sb}$ compound. $\mathrm{Ma}$ et al. [88] reported that Co reinforced Sn3.0Ag0.5Cu composite solder suppressed the growth of IMC layer. It is attributed to Co particles which can attract $\mathrm{Sn}$ and $\mathrm{Cu}$ to form Co-Sn or Co-Cu IMCs during the reflow process. Afterwards, Co close to the interfacial layer can hinder $\mathrm{Cu}$ from being available for formation of the IMC layer and thereby reduce its growth rate. Luo et al. [30] demonstrated that a minor Ga addition has the ability to inhibit the growth of interfacial intermetallic compounds (IMC). It is found that, with the addition of $0.5 \% \mathrm{Ga}$, the thickness of IMC layer is $58.9 \%$ thinner than that of the plain solder/substrate IMC layer. It is explained that Ga can reduce the activity of $\mathrm{Sn}$, thus depressing the growth of $\mathrm{Cu}_{6} \mathrm{Sn}_{5}$ and the excessive reaction of the interface.

The addition of trace amount of RE elements (mainly Ce and $\mathrm{La}$ ) into $\mathrm{SnAgCu}$ solder was investigated by Law et al. [35]. The research achievement shows that a layer of $\mathrm{Cu}_{3} \mathrm{Sn}$ was observed between the $\mathrm{Cu}_{6} \mathrm{Sn}_{5}$ IMC layer and $\mathrm{Cu}$ pad. At the same time, there are many Kirkendall voids between $\mathrm{Cu}_{3} \mathrm{Sn}$ IMC layer and the copper substrate. However, with the addition of RE, the growth of IML was significantly inhibited. Rare earth Y element can show an effective influence on the interfacial growth of IML in SnAgCu solder. With the addition of Y, the thickness of IML was reduced and the growth of the IML was suppressed during the high-temperature aging [36]. Gao et al. [39] note that the addition of $\mathrm{Nd}$ can change the growth of intermetallic layer. When the addition of $\mathrm{Nd}$ was $0.05 \%$, the thickness of IML reduced by $45.8 \%$ compared with the plain solder joint. The reason may be attributed to the formation of $\mathrm{Sn}-\mathrm{Nd}$ compound, thus retarding the growth of the $\mathrm{Cu}_{6} \mathrm{Sn}_{5}$ IMC during the soldering. The advantage of rare earth $\mathrm{Yb}$ addition into $\mathrm{SnAgCu}$ solder was shown by Zhang et al. [40], who found that $0.05 \% \mathrm{Yb}$ addition into $\mathrm{SnAgCu}$ alloy suppressed the growth of IMC and the morphology of $\mathrm{Cu}_{6} \mathrm{Sn}_{5}$ layer can be changed to a relatively flat morphology. Small amounts of La were added to the SnAgCu lead-free solder for studying the growth of the IMC layer between the solder and the $\mathrm{Cu}$ substrate. Comparing the $\mathrm{SnAgCu}$ solder, the IMC thickness has reduced by approximately $60 \%$ with adding trace amount of rare earth La [89]. Liu et al. [90] investigated the effects of addition of Ce on the formation and growth of interfacial IMCs between the $\mathrm{SnAgCu}$ solder joint and $\mathrm{Cu}$ substrate. It is found that the thickness of interfacial IMC can be reduced during the soldering and aging with the addition of Ce into SnAgCu solder. 


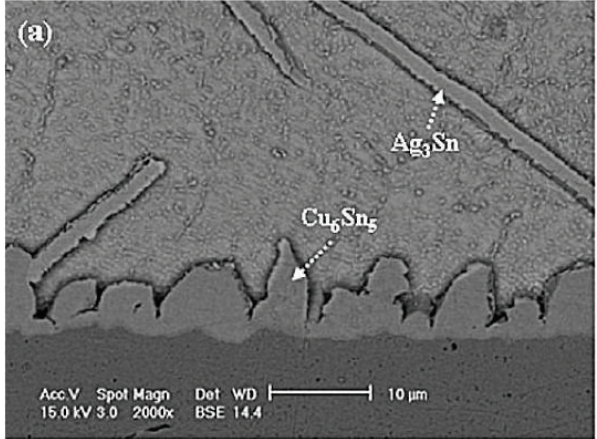

(a)

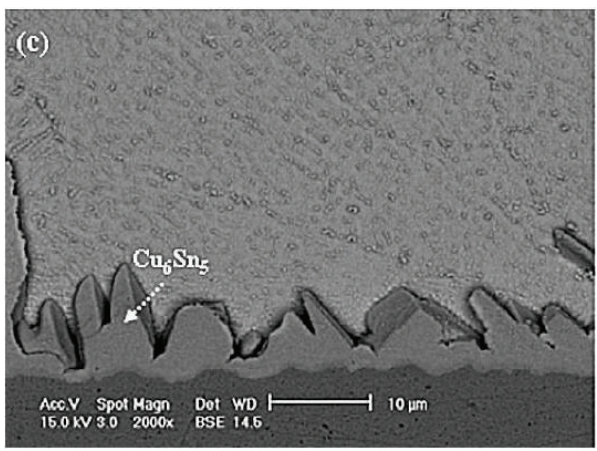

(c)

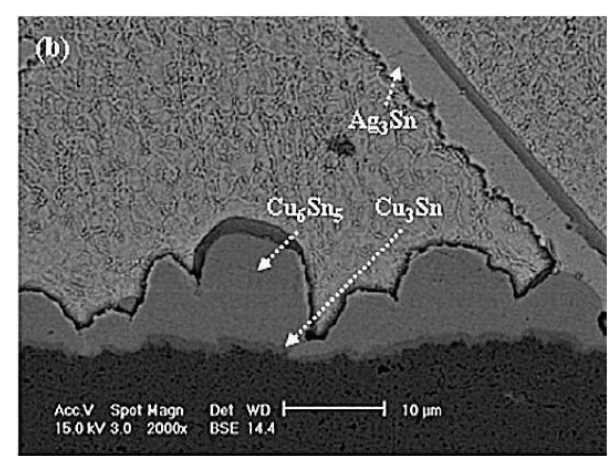

(b)

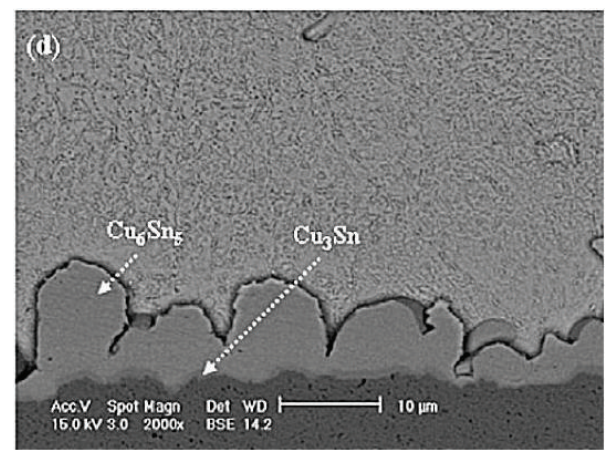

(d)

FIGURE 11: SEM micrographs of ((a) and (b)) SnAgCu and ((c) and (d)) $\mathrm{SnAgCu}-1 \mathrm{TiO}_{2}$ solder joints on $\mathrm{Ag}$ metallized $\mathrm{Cu}$ pads after ((a) and (c)) 8 and ((b) and (d)) 16 reflow cycles [21].

Adding trace amounts of Fe microparticles can restrain the growth of intermetallic compounds (IMCs). During liquid state reaction, $\mathrm{Fe}$ can effectively suppress the growth of $\mathrm{Cu}_{6} \mathrm{Sn}_{5}$ and $\mathrm{Cu}_{3} \mathrm{Sn}$ layer. However, during the reflow process, Fe trended to retard the growth of the $\mathrm{Cu}_{3} \mathrm{Sn}$ layer. Moreover, the total thickness of IMCs for the $\mathrm{SnAgCu}-\mathrm{Fe}$ composite solder was similar to that for the plain $\mathrm{SnAgCu}$ solder [91]. Xiang et al. [18] reported the positive effect of $\mathrm{Mn}$ nanoparticles on the $\mathrm{SnAgCu}$ solder for restricting the growth of intermetallic compounds after first and six times of reflow. However, for $\mathrm{Cu}_{3} \mathrm{Sn}$ thickness, the addition of Mo nanoparticles was not affecting it. The addition of Al nanoparticles can alter the growth of interfacial IMC between $\mathrm{SnAgCu}$ solder alloys and $\mathrm{Cu}$ substrate with 1 cycle and 16 cycles of reflow [57]. When the content of Al nanoparticles was $3 \mathrm{wt} . \%$, the thickness of the IMC decreased from $2.8 \mu \mathrm{m}$ to $2.4 \mu \mathrm{m}$ with one flow cycle. After 16 reflows, the thickness of the IMC decreased from $6.7 \mu \mathrm{m}$ to $6.1 \mu \mathrm{m}$. Ni nanoparticles can also influence the thickness of IMC layer. With the addition of $\mathrm{Ni}$ nanoparticles, the morphology of $\mathrm{Cu}_{6} \mathrm{Sn}_{5}$ changes from a scalloped structure to a planar type after reflow. In addition, the growth of $(\mathrm{Cu}, \mathrm{Ni})_{6} \mathrm{Sn}_{5}$ enhanced, and that of $\mathrm{Cu}_{3} \mathrm{Sn}$ was suppressed [44]. Haseeb et al. [46, 92] investigated the effect of Mo and Co nanoparticles additions on the morphology of interfacial IMCs between $\mathrm{Sn} 3.8 \mathrm{Ag} 0.7 \mathrm{Cu}$ solder and $\mathrm{Cu}$ substrate. It is found that the addition of Mo nanoparticles can decrease the thickness and diameter of $\mathrm{Cu}_{6} \mathrm{Sn}_{5}$. However, the addition of Co nanoparticles can enhance the growth of $\mathrm{Cu}_{6} \mathrm{Sn}_{5}$ and suppress the growth of $\mathrm{Cu}_{3} \mathrm{Sn}$. Due to the fact that Co nanoparticles dissolved in $\mathrm{Cu}_{6} \mathrm{Sn}_{5}$, then change the intermetallic compounds composition. Nevertheless, Mo nanoparticles remain intact without any chemical change or recognizable physical and segregate preferentially at the interfaces. Therefore, they hinder the path for diffusion and restrict the intermetallic compound growth. Chan et al. [93] developed a novel composite solder by incorporating $\mathrm{Zn}$ nanoparticles into $\mathrm{Sn} 3.8 \mathrm{Ag} 0.7 \mathrm{Cu}$ solder, and these $\mathrm{Zn}$ nanoparticles were found to have much decreased the $\mathrm{Cu}_{6} \mathrm{Sn}_{5}$ IMC thickness. When the addition of $\mathrm{Zn}$ nanoparticles was $0.3 \%$, no $\mathrm{Cu}_{5} \mathrm{Zn}_{8}$ can be observed, while with the addition of $0.8 \% \mathrm{Zn}$ nanoparticles, $\mathrm{Cu}_{5} \mathrm{Zn}_{8}$ can be observed and exhibited $1.53 \mu \mathrm{m}$ thickness. After one reflow, $\mathrm{Cu}_{3} \mathrm{Sn}$ was not noticeable. After 6 reflows, the $\mathrm{Cu}_{6} \mathrm{Sn}_{5}$ thickness was reduced with the addition of $\mathrm{Zn}$. When the addition was $0.8 \% \mathrm{Zn}$, the thickness of $\mathrm{Cu}_{6} \mathrm{Sn}_{5}$ reduced from $4.11 \mu \mathrm{m}$ to $0.97 \mu \mathrm{m}$. Meanwhile, the $\mathrm{Cu}_{5} \mathrm{Zn}_{8}$ IMC thickness was increased to $1.72 \mu \mathrm{m}$, and the $\mathrm{Cu}_{3} \mathrm{Sn}$ was found to have a thickness of $0.56 \mu \mathrm{m}$. Tsao and coworkers [58] showed that small amounts of $\mathrm{Al}_{2} \mathrm{O}_{3}$ nanoparticles into $\mathrm{SnAgCu}$ solder suppressed the growth of the IMC thickness during the reflow cycles. Gain et al. [21] found that the addition of $\mathrm{TiO}_{2}$ into $\mathrm{SnAgCu}$ solder reduced the IMC thickness after thermal cycling, as shown in Figure 11. When $\mathrm{ZrO}_{2}$ nanoparticles were added to the $\mathrm{SnAgCu}$ solders, it is found that the intermetallic compounds (IMCs) can be depressed [24]. Fouzder et al. [78] studied Sn3.0Ag0.5Cu composite solder with $90-110 \mathrm{~nm} \mathrm{SrTiO}_{3}$ reinforcement particles and reported significant reduction the IMC layer thickness. With the content of $0.05 \mathrm{wt} . \% \mathrm{SrTiO}_{3}$, 


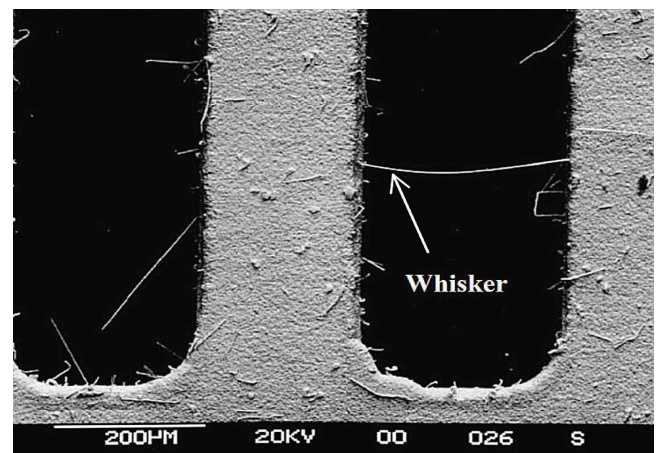

FIGURE 12: SME image of Sn whisker shorting two legs [97].

the IMC thickness was decreased from $6.7 \mu \mathrm{m}$ to $5.8 \mu \mathrm{m}$ after sixteen reflow cycles. Nai et al. [94] added carbon nanotubes (CNTs) to the $\mathrm{Sn} 3.5 \mathrm{Ag} 0.7 \mathrm{Cu}$ solder alloy. Results revealed that, with the addition of CNTs, the nanocomposite solder exhibited a lower diffusion coefficient; thus the growth of IMC layer was retarded. Han et al. [95] also reported a similar effect of Ni-CNTs on the interfacial IMC.

\section{SN Whiskers}

In past reports, the addition of rare earth (RE) elements has showed many beneficial effects. However, with further research, $\mathrm{Pb}$-free solder containing rare earth encountered unexpected problems, namely, Sn whisker. For electronic device, tin whiskers formation is fatal and easily causes short circuits as well as system failures because whiskers can grow to a length exceeding several hundred microns and these tin whiskers are nearly pure single crystals with excellent electrical conductivity [96]. Figure 12 [97] shows a scanning electron image of whiskers on the legs of a lead frame, where a very long whisker can be observed to have bridged a pair of the legs.

In recent years, rare earths were wildly used in the $\mathrm{Pb}$ free solders to enhance solderability. However, as a surfaceactive element, the reactive nature of rare earth elements with oxygen and accelerate tin whisker growth in a rare earth element-containing solder alloy [98]. Hao et al. [99] found that $1.0 \%$ Er doping could form whiskers and the morphology of the Sn whiskers changes from rod-like to thread-like with the storage temperature increases from $25^{\circ} \mathrm{C}$ to $150^{\circ} \mathrm{C}$. Dudek and Chawla [100] also investigated the effect of $2 \mathrm{wt} . \% \mathrm{Ce}, \mathrm{La}$, or Y additions on the whiskering behavior of $\mathrm{Sn} 3.9 \mathrm{Ag} 0.7 \mathrm{Cu}$. It is found that oxidation of $\mathrm{RESn}_{3}$ causes compressive stresses that ultimately result in the formation of $\mathrm{Sn}$ whiskers. Moreover, the size of the $\mathrm{RESn}_{3}$ has a significant impact on oxidation and whiskering:

$$
\begin{gathered}
2 \mathrm{LaSn}_{3}+\frac{3}{2} \mathrm{O}_{2} \longrightarrow \mathrm{La}_{2} \mathrm{O}_{3}+6 \mathrm{Sn} \\
\mathrm{CeSn}_{3}+\mathrm{O}_{2} \longrightarrow \mathrm{CeO}_{2}+3 \mathrm{Sn} \\
2 \mathrm{YSn}_{3}+\frac{3}{2} \mathrm{O}_{2} \longrightarrow \mathrm{Y}_{2} \mathrm{O}_{3}+6 \mathrm{Sn}
\end{gathered}
$$

According to the existing literature, we find that previous research added too much rare earth elements into $\mathrm{SnAgCu}$

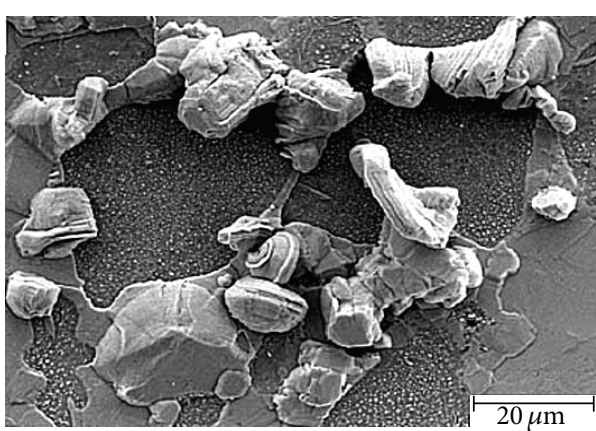

Figure 13: SnAgCu-Ce surface whisker [101].

solder and the minimum addition amount of the rare earth was $1 \%$, thus providing large $\mathrm{RESn}_{3}$ phase for whiskers growth. In order to prevent rapid whisker growth, Chuang and $\mathrm{Lin}$ [101] showed that $0.5 \% \mathrm{Zn}$ addition into $\mathrm{SnAgCu}$ solder refined the microstructure and suppressed whisker growth. Figure 13 shows $\mathrm{SnAgCu}-\mathrm{Ce}$ surface whisker.

Although the addition of alloying elements can suppress the rapid growth of tin whiskers in RE-containing solders, it does not inhibit the emergence of tin whiskers. We think whiskers formation is mainly due to an excess of rare earth elements. Therefore, researchers should control the content of rare earth. It is attributed to addition of trace amounts of rare earth elements; RE phase formation is limited, thereby having difficulty in providing the driving force for whisker growth.

\section{Conclusions}

With the addition of alloying elements and nanoparticles, the wettability, mechanical properties, and hardness properties of $\mathrm{SnAgCu}$ solder and solder joints were enhanced obviously. However, excessive elements can decrease these properties; for example, when adding excessive amounts of rare earth elements, the tin whiskers will appear. And with the addition of excessive amounts of nanoparticles, metal nanoparticles easily react with matrix; thus the phenomenon of grain growth occurs and affects the reliability of solder interconnections. For inert nanoparticles, for example, $\mathrm{Al}_{2} \mathrm{O}_{3}, \mathrm{ZrO}_{2}$, $\mathrm{SiC}$, and so on, they are prone to agglomeration and cause the effect of dispersion strengthening to be lost. Therefore, selecting the appropriate additive amount is very important. In addition, the alloying elements and nanoparticles can refine the microstructure of $\mathrm{SnAgCu}$ solders and the retarding effect of elements on the intermetallic compounds in the solder/copper is also demonstrated.

\section{Conflict of Interests}

The authors declare that there is no conflict of interests regarding the publication of this paper.

\section{Acknowledgments}

This work was supported by the National Natural Science Foundation of China (no. 51475220), the Natural Science 
Foundation of Jiangsu Province (BK2012144), and the Natural Science Foundation of the Higher Education Institutions of Jiangsu Province (12KJB460005).

\section{References}

[1] S. Xu, A. H. Habib, A. D. Pickel, and M. E. McHenry, "Magnetic nanoparticle-based solder composites for electronic packaging applications," Progress in Materials Science, vol. 67, pp. 95-160, 2015.

[2] J. Keller, D. Baither, U. Wilke, and G. Schmitz, "Mechanical properties of $\mathrm{Pb}$-free $\mathrm{SnAg}$ solder joints," Acta Materialia, vol. 59, no. 7, pp. 2731-2741, 2011.

[3] A. A. El-Daly and A. M. El-Taher, "Evolution of thermal property and creep resistance of $\mathrm{Ni}$ and $\mathrm{Zn}$-doped $\mathrm{Sn}-2.0 \mathrm{Ag}$ 0.5Cu lead-free solders," Materials \& Design, vol. 51, pp. 789796, 2013.

[4] A. A. El-Daly and A. E. Hammad, "Enhancement of creep resistance and thermal behavior of eutectic $\mathrm{Sn}-\mathrm{Cu}$ lead-free solder alloy by Ag and In-additions," Materials and Design, vol. 40, pp. 292-298, 2012.

[5] M. R. Shalaby, "Effect of silicon addition on mechanical and electrical properties of $\mathrm{Sn}-\mathrm{Zn}$ based alloys rapidly quenched from melt," Materials Science and Engineering: A, vol. 550, pp. 112-117, 2012.

[6] K. Kanlayasiri, M. Mongkolwongrojn, and T. Ariga, "Influence of indium addition on characteristics of $\mathrm{Sn}-0.3 \mathrm{Ag}-0.7 \mathrm{Cu}$ solder alloy," Journal of Alloys and Compounds, vol. 485, no. 1-2, pp. 225-230, 2009.

[7] C. L. Chuang, L. C. Tsao, H. K. Lin, and L. P. Feng, "Effects of small amount of active Ti element additions on microstructure and property of $\mathrm{Sn} 3.5 \mathrm{Ag} 0.5 \mathrm{Cu}$ solder," Materials Science and Engineering A, vol. 558, pp. 478-484, 2012.

[8] L. W. Lin, J. M. Song, Y. S. Lai, Y. T. Chiu, N. C. Lee, and J. Y. Uan, "Alloying modification of $\mathrm{Sn}-\mathrm{Ag}-\mathrm{Cu}$ solders by manganese and titanium," Microelectronics Reliability, vol. 49, no. 3, pp. 235-241, 2009.

[9] H. Fallahi, M. S. Nurulakmal, A. F. Arezodar, and J. Abdullah, "Effect of iron and indium on IMC formation and mechanical properties of lead-free solder," Materials Science and Engineering A, vol. 553, pp. 22-31, 2012.

[10] A. A. El-Daly, A. E. Hammad, G. S. Al-Ganainy, and M. Ragab, "Influence of $\mathrm{Zn}$ addition on the microstructure, melt properties and creep behavior of low Ag-content Sn-Ag-Cu lead-free solders," Materials Science and Engineering A, vol. 608, pp. 130-138, 2014.

[11] D. A. Shnawah, M. F. M. Sabri, and I. A. Badruddin, "A review on thermal cycling and drop impact reliability of SAC solder joint in portable electronic products," Microelectronics Reliability, vol. 52, no. 1, pp. 90-99, 2012.

[12] M. L. Huang and L. Wang, "Effects of $\mathrm{Cu}, \mathrm{Bi}$, and In on microstructure and tensile properties of $\mathrm{Sn}-\mathrm{Ag}-\mathrm{X}(\mathrm{Cu}, \mathrm{Bi}, \mathrm{In})$ solders," Metallurgical and Materials Transactions A, vol. 36, pp. 1439-1446, 2005.

[13] E. A. Hammad, "Evolution of microstructure, thermal and creep properties of $\mathrm{Ni}$-doped $\mathrm{Sn}-0.5 \mathrm{Ag}-0.7 \mathrm{Cu}$ low-Ag solder alloys for electronic applications," Materials \& Design, vol. 52, pp. 663-670, 2013.

[14] A. A. El-Daly and A. E. Hammad, "Elastic properties and thermal behavior of Sn-Zn based lead-free solder alloys," Journal of Alloys and Compounds, vol. 505, no. 2, pp. 793-800, 2010.
[15] W. X. Dong, Y. W. Shi, Y. P. Lei, Z. D. Xia, and F. Guo, "Effects of trace amounts of rare earth additions on microstructure and properties of Sn-Bi-based solder alloy," Journal of Materials Science: Materials in Electronics, vol. 20, no. 10, pp. 1008-1017, 2009.

[16] C. M. L. Wu and Y. W. Wong, Lead-Free Electronic Solders, 2007.

[17] M. A. Dudek and N. Chawla, "Effect of rare-earth (La, Ce, and $\mathrm{Y})$ additions on the microstructure and mechanical behavior of Sn-3.9Ag-0.7Cu solder alloy," Metallurgical and Materials Transactions A, vol. 41, pp. 610-620, 2010.

[18] K. K. Xiang, A. S. M. A. Haseeb, M. M. Arafat, and Y. X. Goh, "Effects of Mn nanoparticles on wettability and intermetallic compounds in between $\mathrm{Sn}-3.8 \mathrm{Ag}-0.7 \mathrm{Cu}$ and $\mathrm{Cu}$ substrate during multiple reflow," in Proceedings of the 4th Asia Symposium on Quality Electronic Design, pp. 297-301, July 2012.

[19] P. Liu, P. Yao, and J. Liu, "Effect of SiC nanoparticle additions on microstructure and microhardness of $\mathrm{Sn}-\mathrm{Ag}-\mathrm{Cu}$ solder alloy," Journal of Electronic Materials, vol. 37, no. 6, pp. 874-879, 2008.

[20] L. C. Tsao, S. Y. Chang, C. I. Lee, W. H. Sun, and C. H. Huang, "Effects of nano- $\mathrm{Al}_{2} \mathrm{O}_{3}$ additions on microstructure development and hardness of $\mathrm{Sn} 3.5 \mathrm{Ag} 0.5 \mathrm{Cu}$ solder," Materials and Design, vol. 31, no. 10, pp. 4831-4835, 2010.

[21] A. K. Gain, Y. C. Chan, and W. K. C. Yung, "Microstructure, thermal analysis and hardness of a $\mathrm{Sn}-\mathrm{Ag}-\mathrm{Cu}-1 \mathrm{wt} \%$ nano$\mathrm{TiO}_{2}$ composite solder on flexible ball grid array substrates," Microelectronics Reliability, vol. 51, no. 5, pp. 975-984, 2011.

[22] S. Y. Chang, C. C. Jain, T. H. Chuang, L. P. Feng, and L. C. Tsao, "Effect of addition of $\mathrm{TiO}_{2}$ nanoparticles on the microstructure, microhardness and interfacial reactions of Sn3.5AgXCu solder," Materials \& Design, vol. 32, no. 10, pp. 4720-4727, 2011.

[23] A. Fawzy, S. A. Fayek, M. Sobhy, E. Nassr, M. M. Mousa, and G. Saad, "Tensile creep characteristics of $\mathrm{Sn}-3.5 \mathrm{Ag}-0.5 \mathrm{Cu}$ (SAC355) solder reinforced with nano-metric $\mathrm{ZnO}$ particles," Materials Science and Engineering A, vol. 603, pp. 1-10, 2014.

[24] A. K. Gain and Y. C. Chan, "Growth mechanism of intermetallic compounds and damping properties of $\mathrm{Sn}-\mathrm{Ag}-\mathrm{Cu}-1 \mathrm{wt} \%$ nano$\mathrm{ZrO}_{2}$ composite solders," Microelectronics Reliability, vol. 54, no. 5, pp. 945-955, 2014.

[25] S. K. Ghosh, A. S. M. A. Haseeb, and A. Afifi, "Effects of metallic nanoparticle doped flux on interfacial intermetallic compounds between Sn-3.0Ag-0.5Cu and copper substrate," in Proceedings of the IEEE 15th Electronics Packaging Technology Conference (EPTC '13), pp. 21-26, Singapore, December 2013.

[26] Z. Moser, P. Sebo, W. Gąsior, P. Svec, and J. Pstruś, "Effect of indium on wettability of $\mathrm{Sn}-\mathrm{Ag}-\mathrm{Cu}$ solders. Experiment vs. modeling, Part I," Calphad, vol. 33, no. 1, pp. 63-68, 2009.

[27] L. Zhang, J. G. Han, C. W. He, and Y. H. Guo, "Effect of Zn on properties and microstructure of $\mathrm{SnAgCu}$ alloy," Journal of Materials Science: Materials in Electronics, vol. 23, pp. 19501956, 2012.

[28] M. J. Rizvi, Y. C. Chan, C. Bailey, H. Lu, and M. N. Islam, "Effect of adding $1 \mathrm{wt} \% \mathrm{Bi}$ into the $\mathrm{Sn}-2.8 \mathrm{Ag}-0.5 \mathrm{Cu}$ solder alloy on the intermetallic formations with $\mathrm{Cu}$-substrate during soldering and isothermal aging," Journal of Alloys and Compounds, vol. 407, pp. 208-214, 2006.

[29] Z. Moser, W. Gasior, K. Bukat et al., "Pb-free solders, part 1: wettability testing of $\mathrm{Sn}-\mathrm{Ag}-\mathrm{Cu}$ alloys with Bi additions," Journal of Phase Equilibria and Diffusion, vol. 27, no. 2, pp. 133-139, 2006.

[30] D. X. Luo, S. B. Xue, and Z. Q. Li, "Effects of Ga addition on microstructure and properties of $\mathrm{Sn}-0.5 \mathrm{Ag}-0.7 \mathrm{Cu}$ solder," 
Journal of Materials Science: Materials in Electronics, vol. 25, no. 8, pp. 3566-3571, 2014.

[31] N. S. Liu and K. L. Lin, "The effect of Ga content on the wetting reaction and interfacial morphology formed between $\mathrm{Sn}-8.55 \mathrm{Zn}-0.5 \mathrm{Ag}-0.1 \mathrm{Al}-x \mathrm{Ga}$ solders and Cu," Scripta Materialia, vol. 54, no. 2, pp. 219-224, 2006.

[32] S. Lu, F. Luo, J. Chen, and B. H. Wang, in Proceedings of the International Conference on Electronic Packaging Technology \& High Density Packaging, 2008.

[33] C. M. L. Wu, D. Q. Yu, C. M. T. Law, and L. Wang, "Properties of lead-free solder alloys with rare earth element additions," Materials Science and Engineering: R: Reports, vol. 44, no. 1, pp. 1-44, 2004.

[34] D. Q. Yu, J. Zhao, and L. Wang, "Improvement on the microstructure stability, mechanical and wetting properties of $\mathrm{Sn}-\mathrm{Ag}$-Cu lead-free solder with the addition of rare earth elements," Journal of Alloys and Compounds, vol. 376, pp. 170$175,2004$.

[35] C. M. T. Law, C. M. L. Wu, D. Q. Yu, L. Wang, and J. K. L. Lai, "Microstructure, solderability and growth of intermetallic compounds of Sn-Ag-Cu-RE lead-free solder alloys," Journal of Electronic Materials, vol. 35, no. 1, pp. 89-93, 2006.

[36] H. Hao, J. Tian, Y. W. Shi, Y. P. Lei, and Z. D. Xia, "Properties of Sn3.8Ag0.7Cu solder alloy with trace rare earth element y additions," Journal of Electronic Materials, vol. 36, no. 7, pp. 766774, 2007.

[37] Y. Shi, J. Tian, H. Hao, Z. Xia, Y. Lei, and F. Guo, "Effects of small amount addition of rare earth Er on microstructure and property of SnAgCu solder," Journal of Alloys and Compounds, vol. 453, no. 1-2, pp. 180-184, 2008.

[38] L. L. Gao, S. B. Xue, L. Zhang et al., "Effect of praseodymium on the microstructure and properties of $\mathrm{Sn} 3.8 \mathrm{Ag} 0.7 \mathrm{Cu}$ solder," Journal of Materials Science: Materials in Electronics, vol. 21, no. 9, pp. 910-916, 2010.

[39] L. L. Gao, S. B. Xue, L. Zhang, Z. Sheng, G. Zeng, and F. Ji, "Effects of trace rare earth Nd addition on micro structure and properties of SnAgCu solder," Journal of Materials Science: Materials in Electronics, vol. 21, no. 7, pp. 643-648, 2010.

[40] L. Zhang, X. Y. Fan, Y. H. Guo, and C. W. He, "Properties enhancement of $\mathrm{SnAgCu}$ solders containing rare earth $\mathrm{Yb}$," Materials \& Design, vol. 57, pp. 646-651, 2014.

[41] J. X. Wang, S. B. Xue, Z. J. Han et al., "Effects of rare earth $\mathrm{Ce}$ on microstructures, solderability of $\mathrm{Sn}-\mathrm{Ag}-\mathrm{Cu}$ and $\mathrm{Sn}-\mathrm{Cu}-$ Ni solders as well as mechanical properties of soldered joints," Journal of Alloys and Compounds, vol. 467, pp. 219-226, 2009.

[42] X. Y. Zhao, M. Q. Zhao, X. Q. Cui, and M. X. Tong, "Effect of cerium on microstructure and mechanical properties of Sn-Ag$\mathrm{Cu}$ system lead-free solder alloys," Transactions of Nonferrous Metals Society of China, vol. 17, no. 4, pp. 805-810, 2007.

[43] Z. G. Chen, Y. W. Shi, Z. D. Xia, and Y. F. Yan, "Properties of lead-free solder $\mathrm{SnAgCu}$ containing minute amounts of rare earth," Journal of Electronic Materials, vol. 32, no. 4, pp. 235-243, 2003.

[44] S. L. Tay, A. S. M. A. Haseeb, M. R. Johan, P. R. Munroe, and M. Z. Quadir, "Influence of Ni nanoparticle on the morphology and growth of interfacial intermetallic compounds between Sn-3.8Ag-0.7Cu lead-free solder and copper substrate," Intermetallics, vol. 33, pp. 8-15, 2013.

[45] J.-W. Yoon, S.-W. Kim, and S.-B. Jung, "IMC morphology, interfacial reaction and joint reliability of $\mathrm{Pb}$-free $\mathrm{Sn}-\mathrm{Ag}-\mathrm{Cu}$ solder on electrolytic Ni BGA substrate," Journal of Alloys and Compounds, vol. 392, no. 1-2, pp. 247-252, 2005.
[46] A. S. M. A. Haseeb and T. S. Leng, "Effects of Co nanoparticle addition to $\mathrm{Sn}-3.8 \mathrm{Ag}-0.7 \mathrm{Cu}$ solder on interfacial structure after reflow and ageing," Intermetallics, vol. 19, no. 5, pp. 707-712, 2011.

[47] S. L. Tay, A. S. M. A. Haseeb, and M. R. Johan, "Addition of cobalt nanoparticles into $\mathrm{Sn}-3.8 \mathrm{Ag}-0.7 \mathrm{Cu}$ lead-free solder by paste mixing," Soldering and Surface Mount Technology, vol. 23, no. 1, pp. 10-14, 2011.

[48] Y. Li, C. X. Zhao, Y. Liu, and Y. Wang, "Effect of $\mathrm{TiO}_{2}$ addition concentration on the wettability and intermetallic compounds growth of $\mathrm{Sn} 3.0 \mathrm{Ag} 0.5 \mathrm{Cu}-\mathrm{xTiO}_{2}$ nano-composite solders," Journal of Materials Science: Materials in Electronics, vol. 25, no. 9, pp. 3816-3827, 2014.

[49] X. D. Liu, Y. D. Han, H. Y. Jing, J. Wei, and L. Y. Xu, "Effect of graphene nanosheets reinforcement on the performance of SnAg-Cu lead-free solder," Materials Science and Engineering A, vol. 562, pp. 25-32, 2013.

[50] S. M. L. Nai, J. Wei, and M. Gupta, "Lead-free solder reinforced with multiwalled carbon nanotubes," Journal of Electronic Materials, vol. 35, no. 7, pp. 1518-1522, 2006.

[51] Y. D. Han, S. M. L. Nai, H. Y. Jing, L. Y. Xu, C. M. Tan, and J. Wei, "Development of a Sn-Ag-Cu solder reinforced with Ni-coated carbon nanotubes," Journal of Materials Science: Materials in Electronics, vol. 22, no. 3, pp. 315-322, 2011.

[52] V. Kripesh, M. Teo, C. T. Tai, G. Vishwanadam, and Y. C. Mui, "Development of a lead free chip scale package for wireless applications," in Proceedings of the 51st Electronic Components and Technology Conference, pp. 665-670, June 2001.

[53] H. Y. Song, Q. S. Zhu, Z. G. Wang, J. K. Shang, and M. Lu, "Effects of $Z n$ addition on microstructure and tensile properties of Sn-1Ag-0.5Cu alloy," Materials Science and Engineering A, vol. 527, no. 6, pp. 1343-1350, 2010.

[54] A. A. El-Daly and A. M. El-Taher, "Improved strength of Ni and $\mathrm{Zn}$-doped $\mathrm{Sn}-2.0 \mathrm{Ag}-0.5 \mathrm{Cu}$ lead-free solder alloys under controlled processing parameters," Materials \& Design, vol. 47, pp. 607-614, 2013.

[55] G. Y. Li, B. L. Chen, X. Q. Shi, S. C. K. Wong, and Z. F. Wang, "Effects of Sb addition on tensile strength of Sn-3.5Ag-0.7Cu solder alloy and joint," Thin Solid Films, vol. 504, no. 1-2, pp. 421-425, 2006.

[56] Y. F. Yan, J. H. Zhu, F. X. Chen, J. G. He, and D. X. Yang, “Creep behavior on Ag particle reinforced $\mathrm{SnCu}$ based composite solder joints," Transactions of Nonferrous Metals Society, vol. 16, pp. 1116-1200, 2006.

[57] A. K. Gain, T. Fouzder, Y. C. Chan, A. Sharif, N. B. Wong, and W. K. C. Yung, "The influence of addition of $\mathrm{Al}$ nano-particles on the microstructure and shear strength of eutectic Sn-Ag$\mathrm{Cu}$ solder on $\mathrm{Au} / \mathrm{Ni}$ metallized $\mathrm{Cu}$ pads," Journal of Alloys and Compounds, vol. 506, no. 1, pp. 216-223, 2010.

[58] L. C. Tsao, R. W. Wu, T. H. Cheng, K. H. Fan, and R. S. Chen, "Effects of nano- $\mathrm{Al}_{2} \mathrm{O}_{3}$ particles on microstructure and mechanical properties of $\mathrm{Sn} 3.5 \mathrm{Ag} 0.5 \mathrm{Cu}$ composite solder ball grid array joints on Sn/Cu pads," Materials \& Design, vol. 50, pp. 774-781, 2013.

[59] Y. Tang, G. Y. Li, and Y. C. Pan, "Effects of $\mathrm{TiO}_{2}$ nanoparticles addition on microstructure, microhardness and tensile properties of $\mathrm{Sn}-3.0 \mathrm{Ag}-0.5 \mathrm{C}-\mathrm{xTiO}_{2}$ composite solder," Materials \& Design, vol. 55, pp. 574-582, 2014.

[60] A. Roshanghias, A. H. Kokabi, Y. Miyashita, Y. Mutoh, M. Rezayat, and H. R. Madaah-Hosseini, "Ceria reinforced nanocomposite solder foils fabricated by accumulative roll bonding process," Journal of Materials Science: Materials in Electronics, vol. 23, no. 9, pp. 1698-1704, 2012. 
[61] S. M. L. Nai, J. Wei, and M. Gupta, "Influence of ceramic reinforcements on the wettability and mechanical properties of novel lead-free solder composites," Thin Solid Films, vol. 504, no. 1-2, pp. 401-404, 2006.

[62] Z. B. Yang, W. Zhou, and P. Wu, "Effects of Ni-coated carbon nanotubes addition on the microstructure and mechanical properties of Sn-Ag-Cu solder alloys," Materials Science and Engineering: A, vol. 590, pp. 295-300, 2014.

[63] K. M. Kumar, V. Kripesh, and A. A. O. Tay, "Single-wall carbon nanotube (SWCNT) functionalized Sn-Ag-Cu lead-free composite solders," Journal of Alloys and Compounds, vol. 450, no. 1-2, pp. 229-237, 2008.

[64] X. Hu, Y. C. Chan, K. Zhang, and K. C. Yung, "Effect of graphene doping on microstructural and mechanical properties of Sn$8 \mathrm{Zn}-3 \mathrm{Bi}$ solder joints together with electromigration analysis," Journal of Alloys and Compounds, vol. 580, pp. 162-171, 2013.

[65] Y. C. Zhou, Q. L. Pan, Y. B. He et al., "Microstructures and properties of $\mathrm{Sn}$-Ag-Cu lead-free solder alloys containing La," Transactions of Nonferrous Metals Society of China, vol. 17, supplement 1, pp. s1043-s1048, 2007.

[66] A. K. Gain and Y. C. Chan, "The influence of a small amount of $\mathrm{Al}$ and $\mathrm{Ni}$ nano-particles on the microstructure, kinetics and hardness of Sn-Ag-Cu solder on OSP-Cu pads," Intermetallics, vol. 29, pp. 48-55, 2012.

[67] K. Mohankumar and A. A. O. Tay, in Proceedings of 6th Electronics Packaging Technology Conference, 2004.

[68] J. Shen, C. F. Peng, H. G. Yin, and J. Chen, "Influence of minor POSS molecules additions on the microstructure and hardness of $\mathrm{Sn} 3 \mathrm{Ag} 0.5 \mathrm{Cu}$-xPOSS composite solders," Journal of Materials Science: Materials in Electronics, vol. 23, pp. 1640-1646, 2012.

[69] L. Zhang and K. N. Tu, "Structure and properties of lead-free solders bearing micro and nano particles," Materials Science and Engineering: R: Reports, vol. 82, pp. 1-32, 2014.

[70] D. A. Shnawah, M. F. M. Sabri, I. A. Badruddin, S. B. M. Said, T. Ariga, and F. X. Che, "Effect of ag content and the minor alloying element fe on the mechanical properties and microstructural stability of $\mathrm{Sn}-\mathrm{Ag}$-Cu solder alloy under hightemperature annealing," Journal of Electronic Materials, vol. 42, no. 3, pp. 470-484, 2013.

[71] M. F. M. Sabri, D. A. Shnawah, I. A. Badruddin, S. B. M. Said, F. X. Che, and T. Ariga, "Microstructural stability of Sn-1Ag$0.5 \mathrm{Cu}-\mathrm{xAl}(\mathrm{x}=1,1.5$, and $2 \mathrm{wt} . \%)$ solder alloys and the effects of high-temperature aging on their mechanical properties," Materials Characterization, vol. 78, pp. 129-143, 2013.

[72] A. E. Hammad, "Investigation of microstructure and mechanical properties of novel $\mathrm{Sn}-0.5 \mathrm{Ag}-0.7 \mathrm{Cu}$ solders containing small amount of Ni," Materials \& Design, vol. 50, pp. 108-116, 2013.

[73] A. A. El-Daly, A. M. El-Taher, and T. R. Dalloul, "Enhanced ductility and mechanical strength of Ni-doped Sn-3.0Ag-0.5Cu lead-free solders," Materials and Design, vol. 55, pp. 309-318, 2014.

[74] B. L. Chen and G. Y. Li, "Influence of Sb on IMC growth in $\mathrm{Sn}-\mathrm{Ag}-\mathrm{Cu}-\mathrm{Sb} \mathrm{Pb}$-free solder joints in reflow process," Thin Solid Films, vol. 462-463, pp. 395-401, 2004.

[75] Q. Zhai J, S. K. Guan, and G. Y. Shang, Alloy Thermo-Mechanism: Theory and Applications, Metallurgy Industry Press, Beijing, China, 1999.

[76] Z. G. Chen, Y. W. Shi, Z. D. Xia, and Y. F. Yan, "Study on the microstructure of a novel lead-free solder alloy $\mathrm{SnAgCu}-\mathrm{RE}$ and its soldered joints," Journal of Electronic Materials, vol. 31, no. 10, pp. 1122-1128, 2002.
[77] L. Zhang, X. Y. Fan, Y. H. Guo, and C. W. He, "Microstructures and fatigue life of $\mathrm{SnAgCu}$ solder joints bearing Nano-Al particles in QFP devices," Electronic Materials Letters, vol. 10, no. 3, pp. 645-647, 2014.

[78] T. Fouzder, I. Shafiq, Y. C. Chan, A. Sharif, and W. K. C. Yung, "Influence of $\mathrm{SrTiO}_{3}$ nano-particles on the microstructure and shear strength of $\mathrm{Sn}-\mathrm{Ag}-\mathrm{Cu}$ solder on $\mathrm{Au} / \mathrm{Ni}$ metallized $\mathrm{Cu}$ pads," Journal of Alloys and Compounds, vol. 509, no. 5, pp. 18851892, 2011.

[79] A. K. Gain, Y. C. Chan, and W. K. C. Yung, "Effect of additions of $\mathrm{ZrO}_{2}$ nano-particles on the microstructure and shear strength of $\mathrm{Sn}-\mathrm{Ag}-\mathrm{Cu}$ solder on $\mathrm{Au} / \mathrm{Ni}$ metallized $\mathrm{Cu}$ pads," Microelectronics Reliability, vol. 51, no. 12, pp. 2306-2313, 2011.

[80] K. Upadhya, in Proceedings of the Symposium Sponsored by the Structural Materials Division of TMS Annual Meeting, 1993.

[81] J. X. Liang, T. B. Luo, A. M. Hu, and M. Li, "Formation and growth of interfacial intermetallic layers of $\mathrm{Sn}-8 \mathrm{Zn}-3 \mathrm{Bi}-0.3 \mathrm{Cr}$ on $\mathrm{Cu}, \mathrm{Ni}$ and Ni-W substrates," Microelectronics Reliability, vol. 54, no. 1, pp. 245-251, 2014.

[82] K. N. Tu and K. Zeng, "Tin-lead ( $\mathrm{SnPb}$ ) solder reaction in flip chip technology," Materials Science and Engineering R: Reports, vol. 34, no. 1, pp. 1-58, 2001.

[83] G. Zeng, S. Xue, L. Zhang, L. Gao, W. Dai, and J. Luo, "A review on the interfacial intermetallic compounds between Sn-Ag$\mathrm{Cu}$ based solders and substrates," Journal of Materials Science: Materials in Electronics, vol. 21, no. 5, pp. 421-440, 2010.

[84] T. Laurila, V. Vuorinen, and J. K. Kivilahti, "Interfacial reactions between lead-free solders and common base materials," Materials Science and Engineering R: Reports, vol. 49, no. 1-2, pp. 1-60, 2005.

[85] W. Peng, E. Monlevade, and M. E. Marques, "Effect of thermal aging on the interfacial structure of $\mathrm{SnAgCu}$ solder joints on Cu," Microelectronics Reliability, vol. 47, no. 12, pp. 2161-2168, 2007.

[86] C. Lejuste, F. Hodaj, and L. Petit, "Solid state interaction between a $\mathrm{Sn}-\mathrm{Ag}-\mathrm{Cu}-\mathrm{In}$ solder alloy and $\mathrm{Cu}$ substrate," Intermetallics, vol. 36, pp. 102-108, 2013.

[87] F.-J. Wang, F. Gao, X. Ma, and Y.-Y. Qian, "Depressing effect of $0.2 \mathrm{wt} . \% \mathrm{Zn}$ addition into $\mathrm{Sn}-3.0 \mathrm{Ag}-0.5 \mathrm{Cu}$ solder alloy on the intermetallic growth with $\mathrm{Cu}$ substrate during isothermal aging," Journal of Electronic Materials, vol. 35, no. 10, pp. 1818$1824,2006$.

[88] L. M. Ma, F. Tai, G. C. Xu, F. Guo, and X. T. Wang, "Effects of processing and amount of co addition on shear strength and microstructual development in the Sn-3.0Ag- $0.5 \mathrm{Cu}$ solder joint," Journal of Electronic Materials, vol. 40, no. 6, pp. 14161421, 2011.

[89] M. A. Dudek, R. S. Sidhu, N. Chawla, and M. Renavikar, "Microstructure and mechanical behavior of novel rare earthcontaining Pb-free solders," Journal of Electronic Materials, vol. 35, no. 12, pp. 2088-2097, 2006.

[90] X. Liu, L. F. Wang, J. Wang, and Y. Lv, in Proceedings of the 11th International Conference on Electronic Packaging Technalogy \& High Density Packaging, 2010.

[91] X. Y. Liu, M. L. Huang, N. Zhao, and L. Wang, "Liquidstate and solid-state interfacial reactions between $\mathrm{Sn}-\mathrm{Ag}-\mathrm{Cu}-$ Fe composite solders and $\mathrm{Cu}$ substrate," Journal of Materials Science: Materials in Electronics, vol. 25, pp. 328-337, 2014.

[92] A. S. M. A. Haseeb, M. M. Arafat, and M. R. Johan, "Stability of molybdenum nanoparticles in $\mathrm{Sn}-3.8 \mathrm{Ag}-0.7 \mathrm{Cu}$ solder during 
multiple reflow and their influence on interfacial intermetallic compounds," Materials Characterization, vol. 64, pp. 27-35, 2012.

[93] Y. H. Chan, M. M. Arafat, and A. S. M. A. Haseeb, "Effects of reflow on the interfacial characteristics between $\mathrm{Zn}$ nanoparticles containing Sn-3.8Ag-0.7Cu solder and copper substrate," Soldering and Surface Mount Technology, vol. 25, no. 2, pp. 9198, 2013.

[94] S. M. L. Nai, J. Wei, and M. Gupta, "Interfacial intermetallic growth and shear strength of lead-free composite solder joints," Journal of Alloys and Compounds, vol. 473, no. 1-2, pp. 100-106, 2009.

[95] Y. D. Han, H. Y. Jing, S. M. L. Nai, L. Y. Xu, C. M. Tan, and J. Wei, "Interfacial reaction and shear strength of Ni-coated carbon nanotubes reinforced $\mathrm{Sn}-\mathrm{Ag}-\mathrm{Cu}$ solder joints during thermal cycling," Intermetallics, vol. 31, pp. 72-78, 2012.

[96] G. T. Galyon, "Annotated tin whisker bibliography and anthology," IEEE Transactions on Electronics Packaging Manufacturing, vol. 28, no. 1, pp. 94-122, 2005.

[97] K. N. Tu, Solder Joint Technology: Materials, Properties, and Reliability, Springer Series in Materials Science, Springer, 2007.

[98] T.-H. Chuang, "Rapid whisker growth on the surface of Sn-3Ag$0.5 \mathrm{Cu}-1.0 \mathrm{Ce}$ solder joints," Scripta Materialia, vol. 55, no. 11, pp. 983-986, 2006.

[99] H. Hao, Y. W. Shi, Z. D. Xia, Y. P. Lei, and F. Guo, “Oxidizationinduced tin whisker growth on the surface of Sn-3.8Ag- $0.7 \mathrm{Cu}-$ 1.0Er alloy," Metallurgical and Materials Transactions A, vol. 40, no. 8, pp. 2016-2021, 2009.

[100] M. A. Dudek and N. Chawla, "Mechanisms for Sn whisker growth in rare earth-containing Pb-free solders," Acta Materialia, vol. 57, no. 15, pp. 4588-4599, 2009.

[101] T. H. Chuang and H. J. Lin, "Inhibition of whisker growth on the surface of Sn-3Ag-0.5Cu-0.5Ce solder alloyed with Zn," Journal of Electronic Materials, vol. 38, no. 3, pp. 420-424, 2009. 

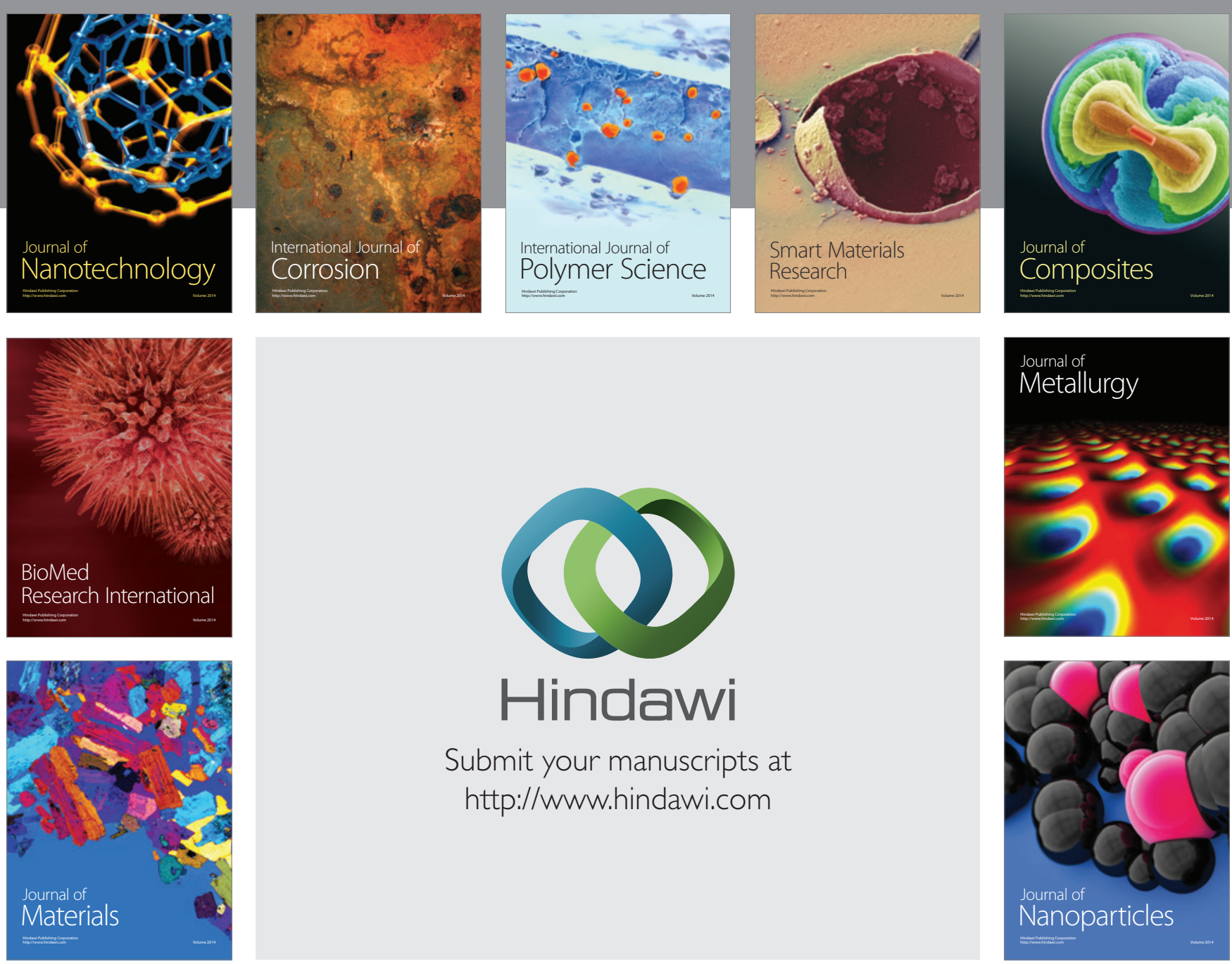

Submit your manuscripts at http://www.hindawi.com
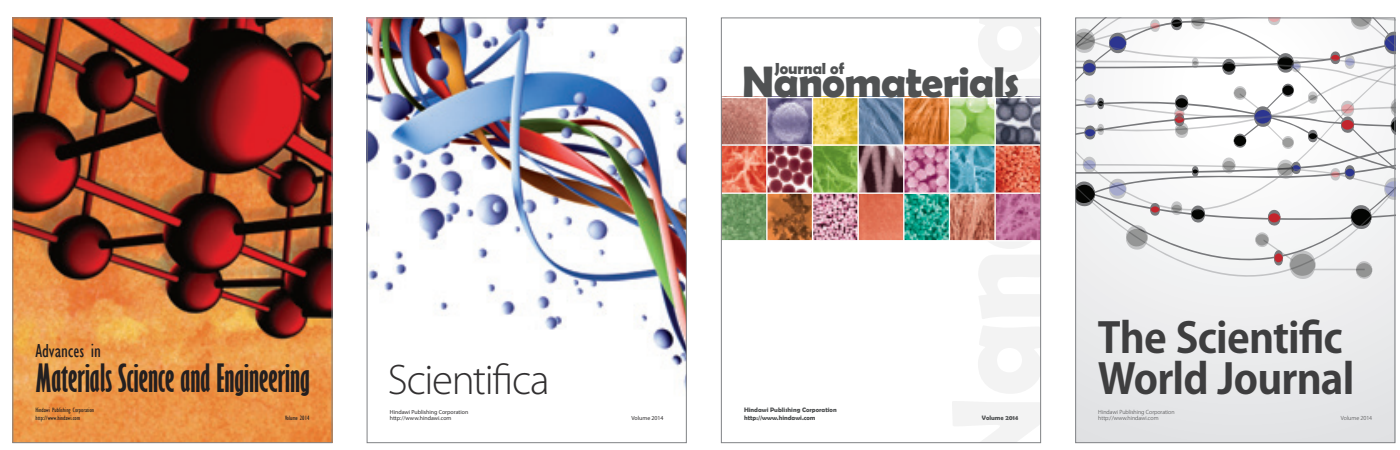

\section{The Scientific World Journal}
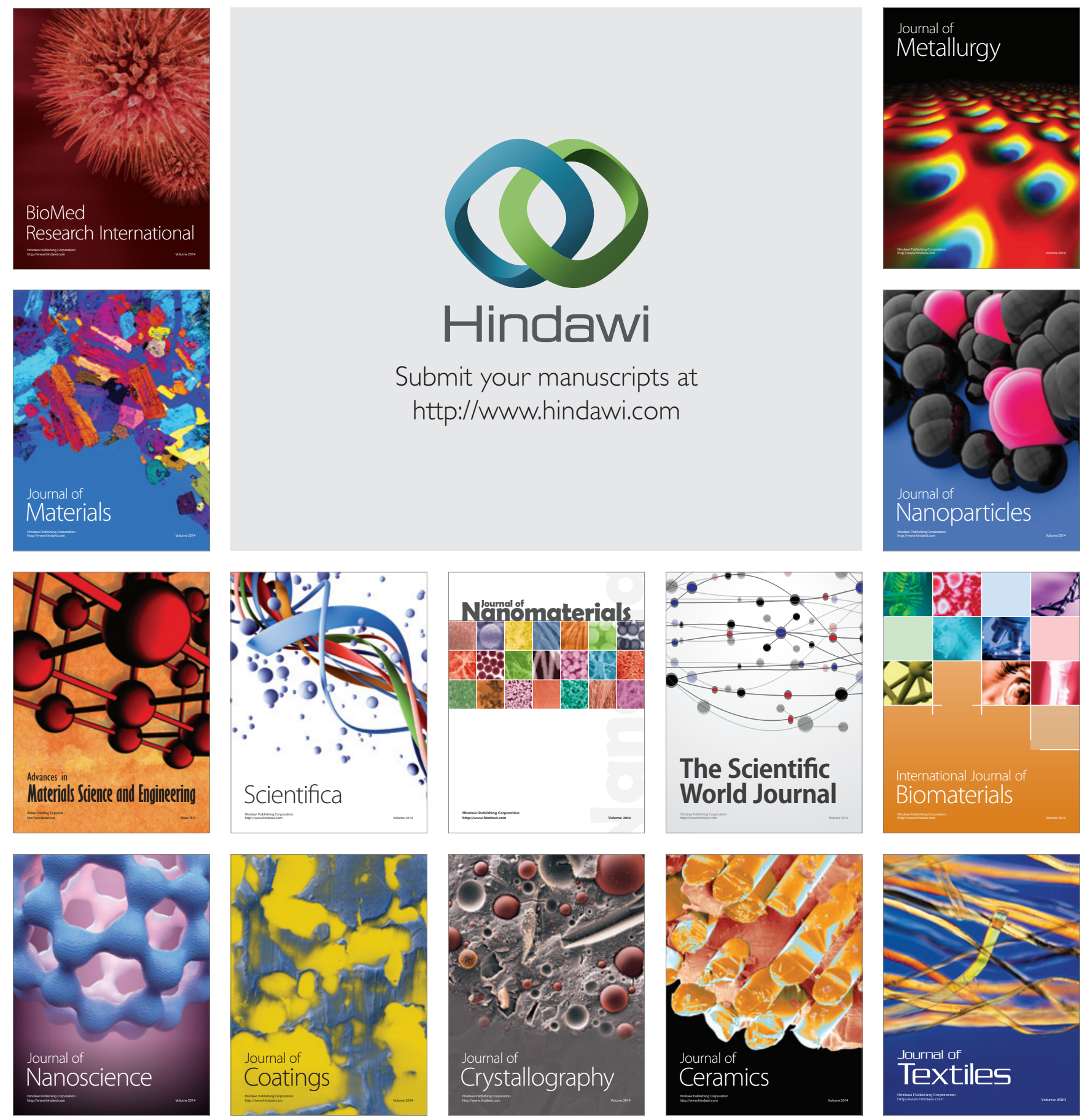